J. Product. \& Dev., 22(2): 355-376(2017)

كفاعة إستخدام المرشدين لمصادر المعلومات الزراعية فى محافظتى الشرقية

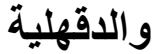

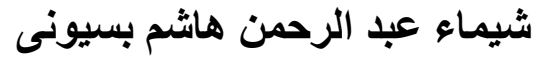

الإرشاد الزر اعى- كلية الزر اعة- جامعة الزقازيقـ- الزقازيق- مصر.

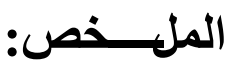

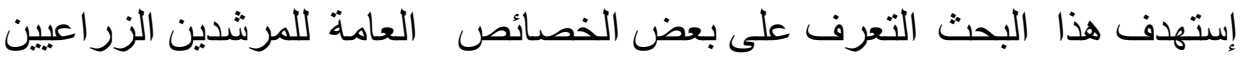

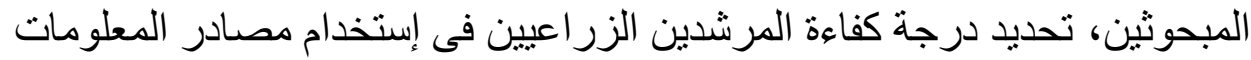

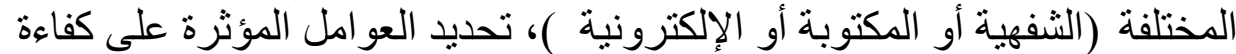

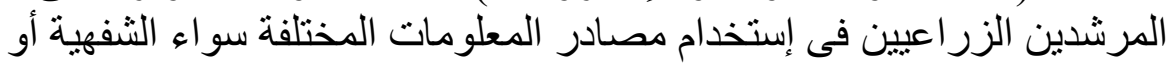

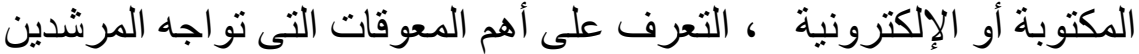

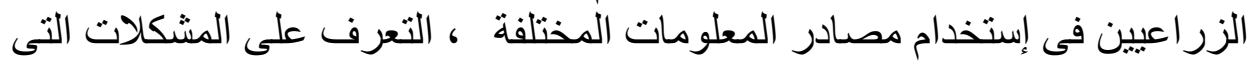

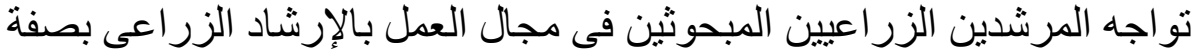

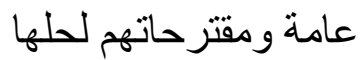

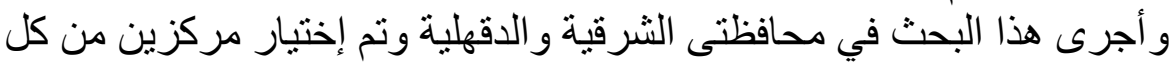

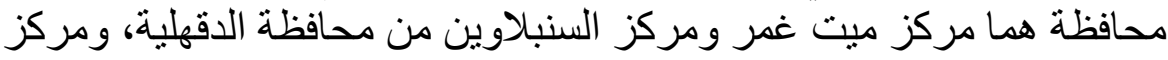

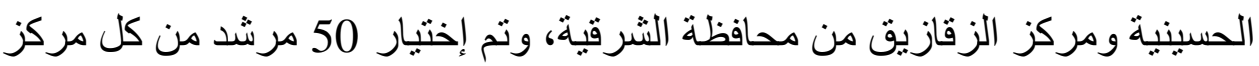

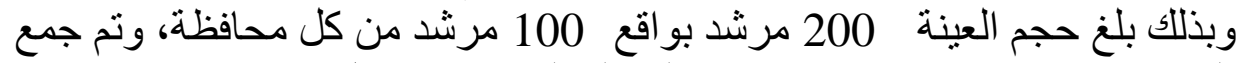

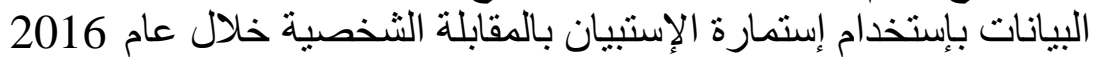

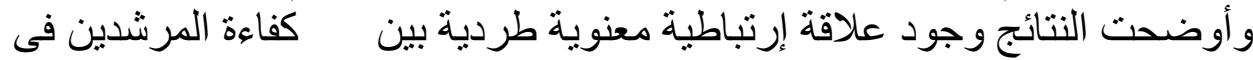

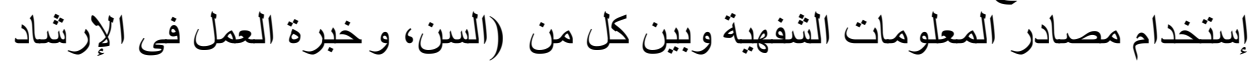

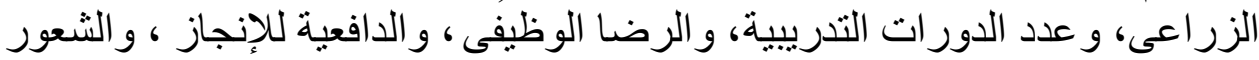

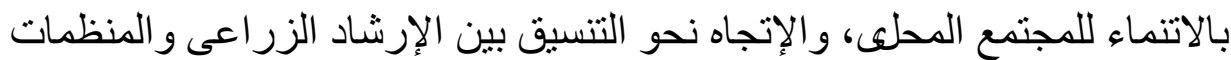

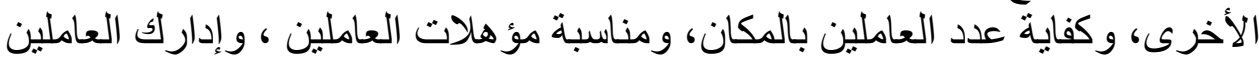

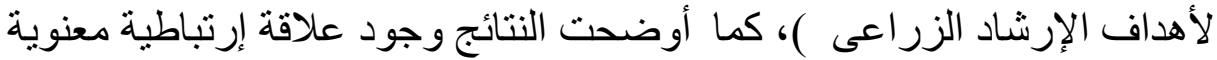

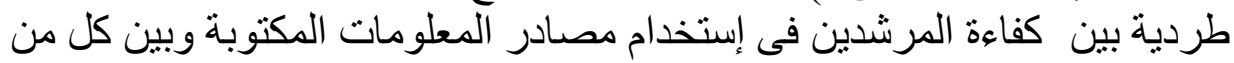

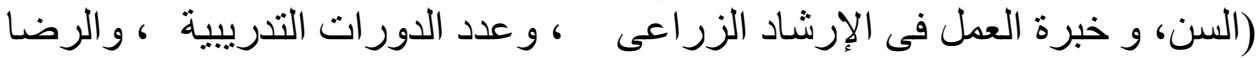

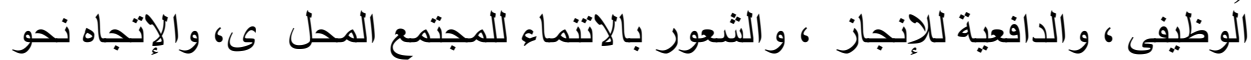

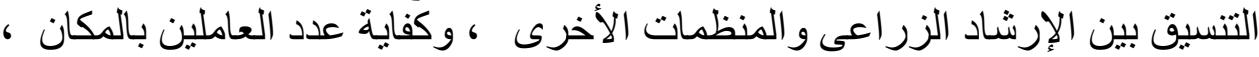

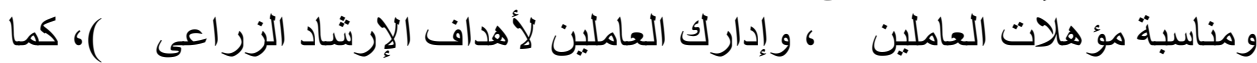

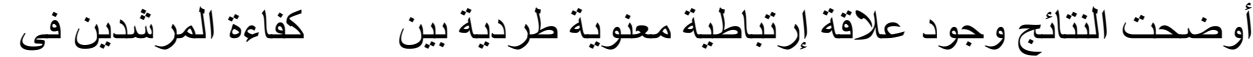

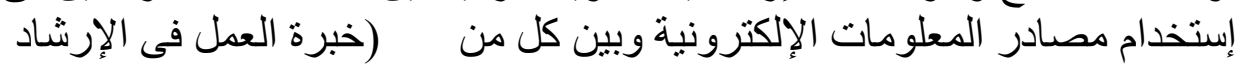
الزر اعى، و عدد الدورات التنريبية، و الرضيا الوظيفى ، و الدافعية للإنجاز ، و الثعور 
بالاتتماء للمجتمع المحلى، و الإتجاه نحو التنسيق بين الإرشاد الزر اعى و المنظمات

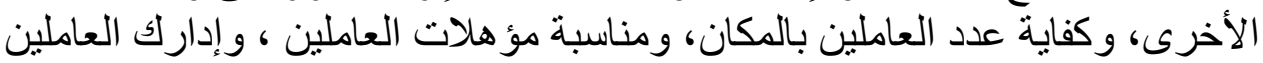

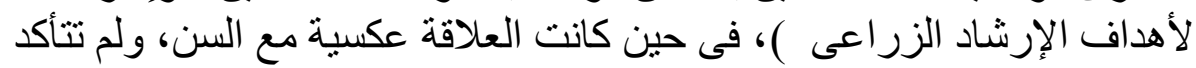

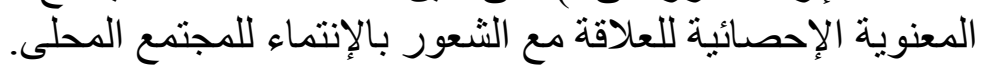

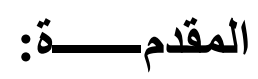

يعيش عالم اليو مرحلة انتقال نوعى حاد وسريع لأنه ينتقل علميا وتاريخيا من

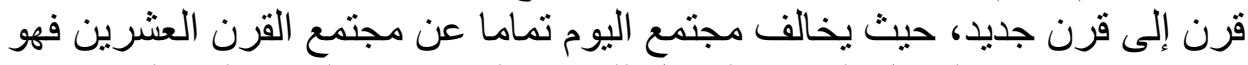

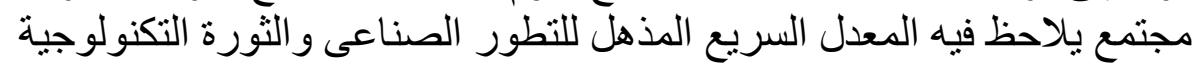

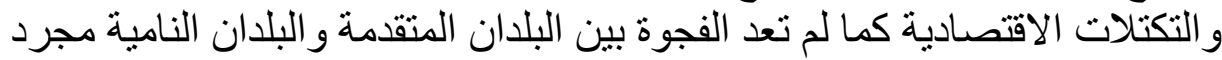

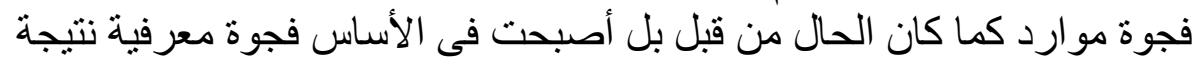

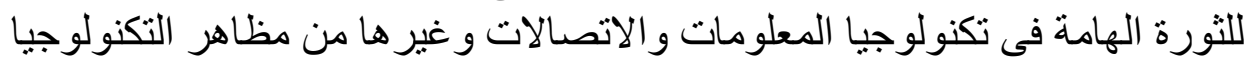

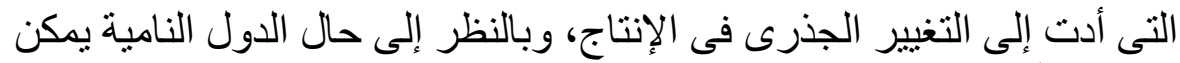

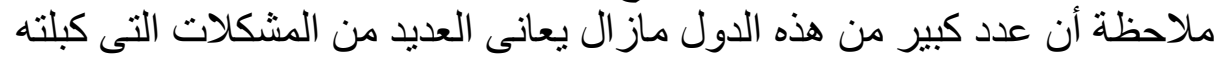

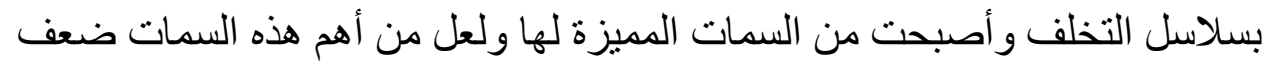

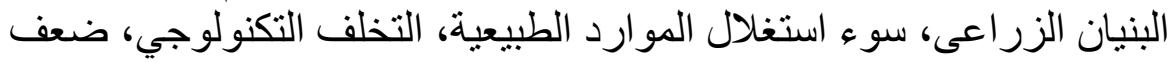

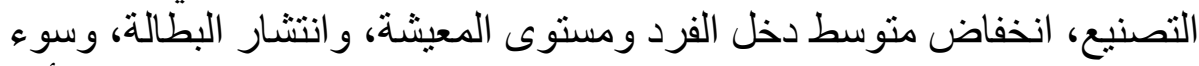

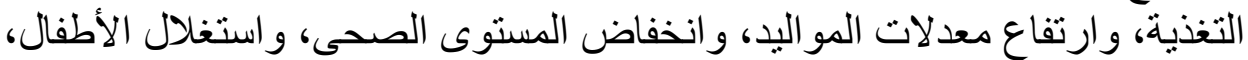

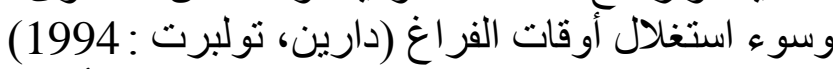

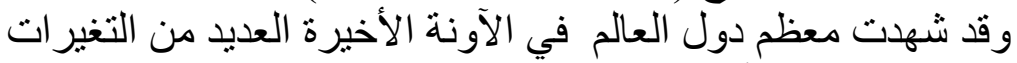

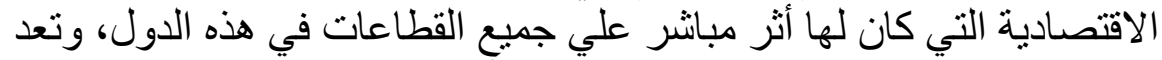

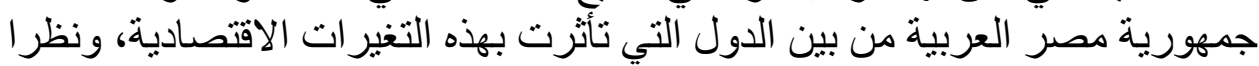

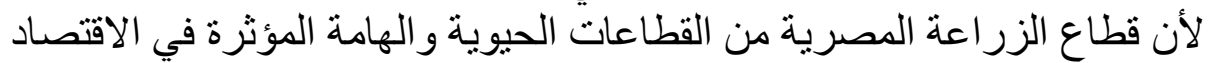

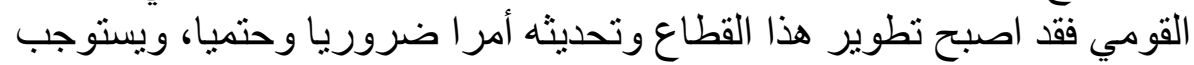

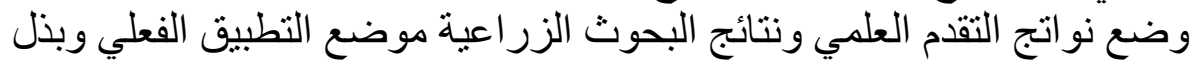

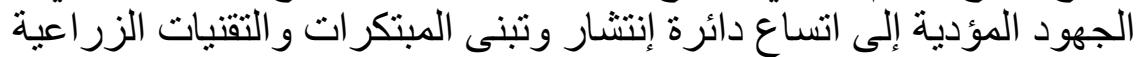

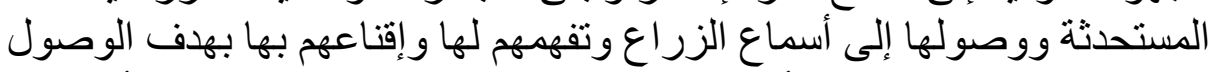

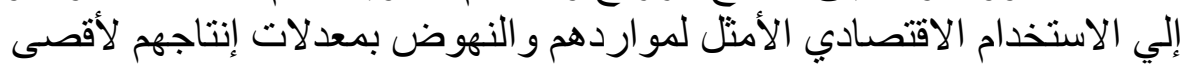

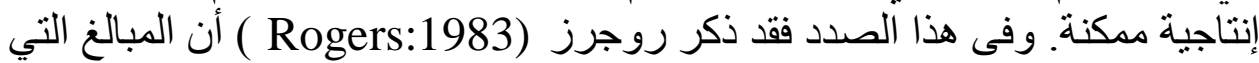

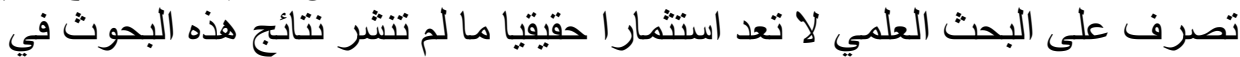

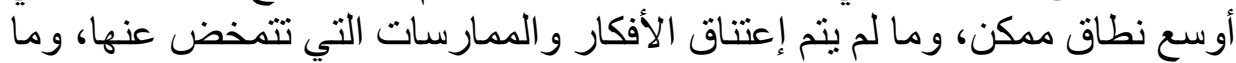

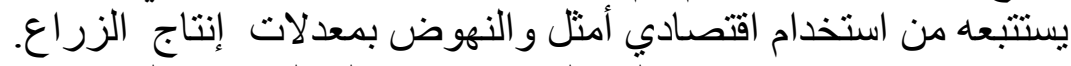

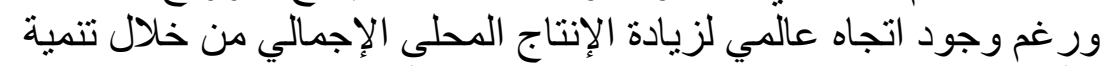

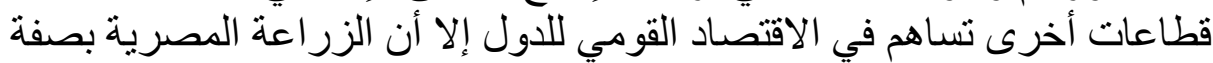


خاصة ماز الت تمتلك إمكانيات هائلة للنمو وزيادة تصدير المنتجات الزر اعية، ونظر الأن التتمية الزر اعية تعد إحدى الركائز الأساسية التى تعتمد عليها التنمية

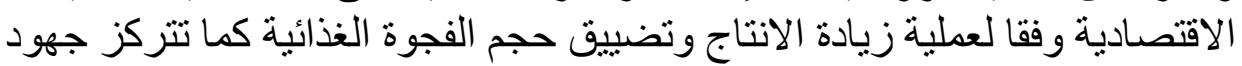

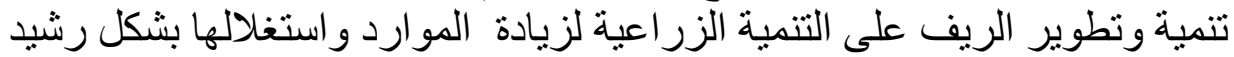

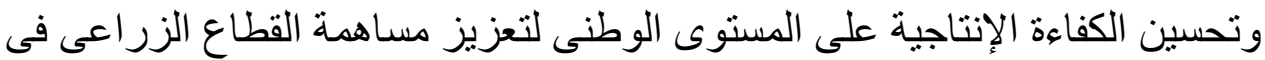

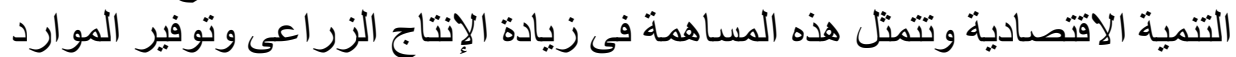

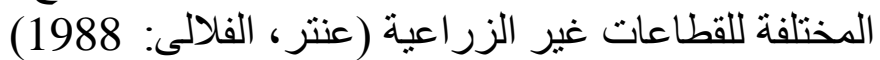

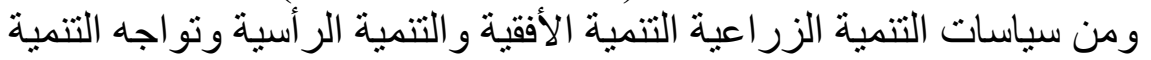

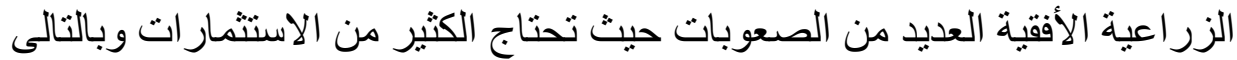

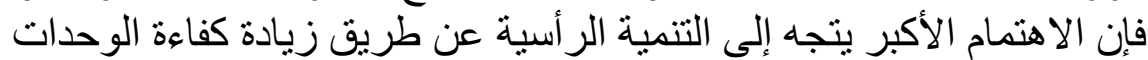

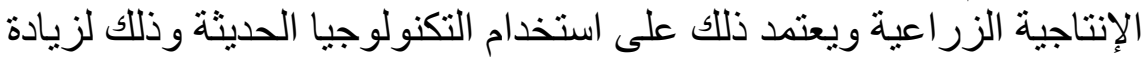

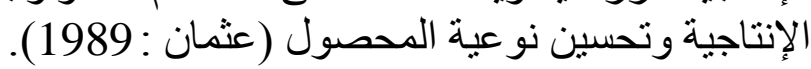

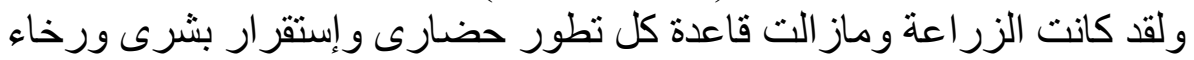

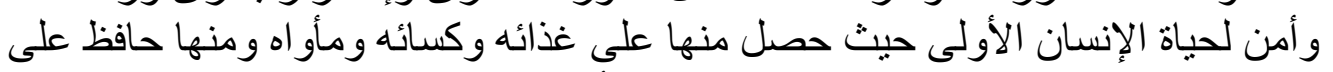
صحته وتفنن فى رفاهيته حيث تعقدت حياته وبدأ يتعلم مالم يكن يعلم عن بيئته ودنياه

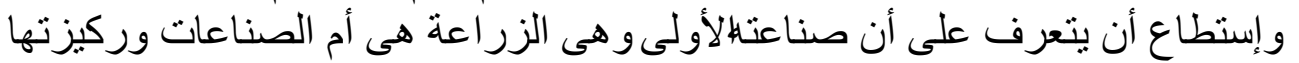

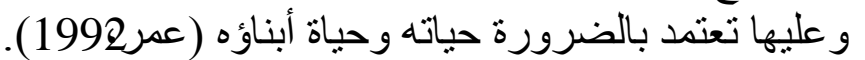

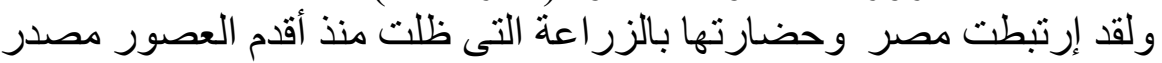

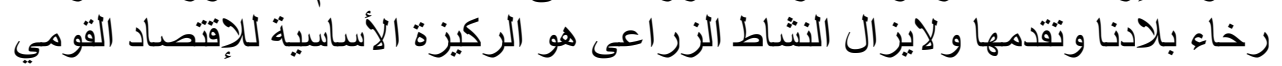

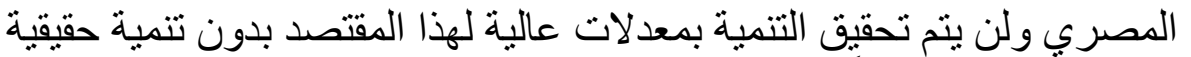

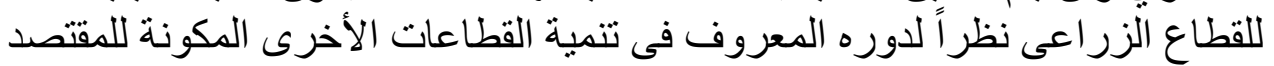
المصرى (هجرس، 1996).

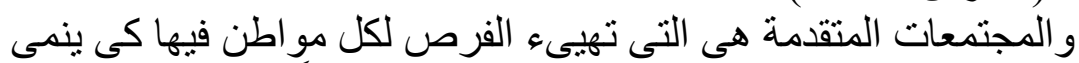

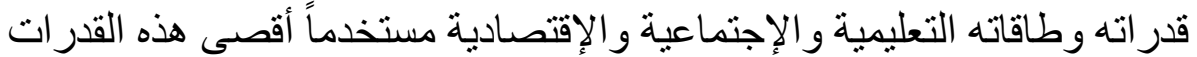

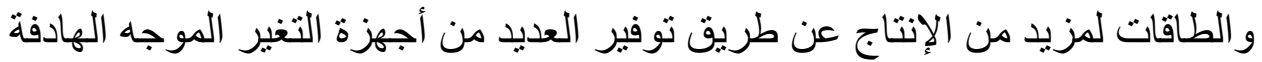

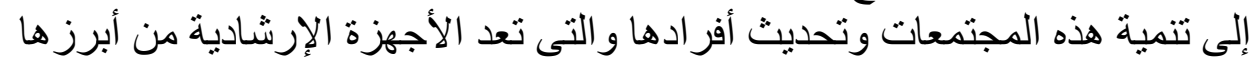

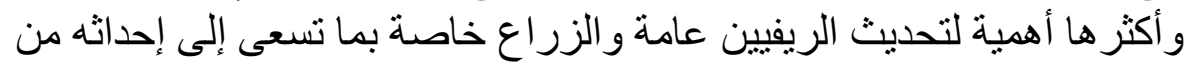

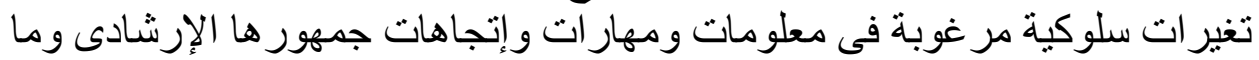

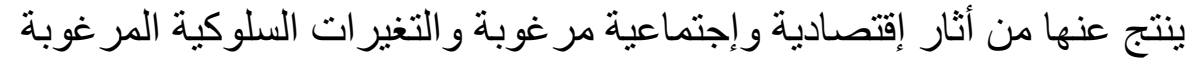

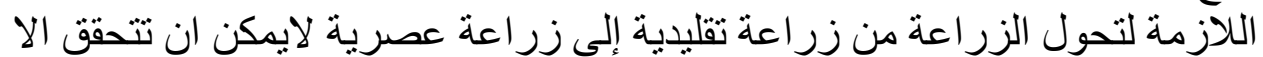

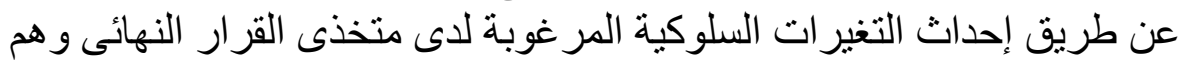

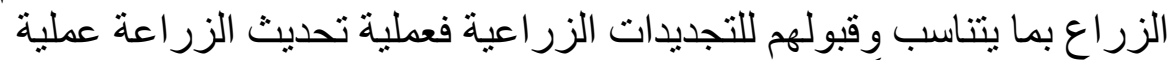

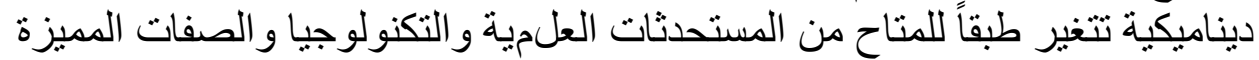

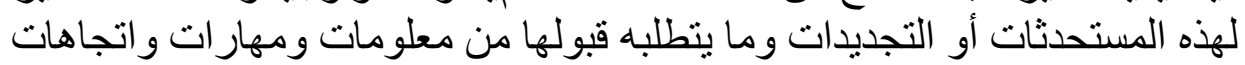




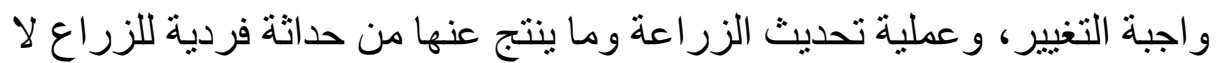

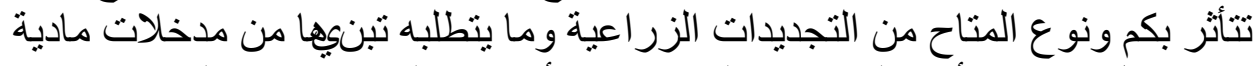

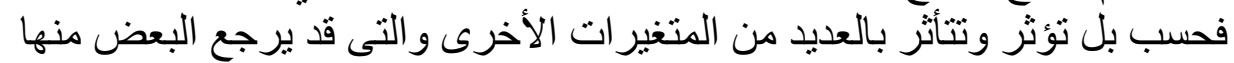

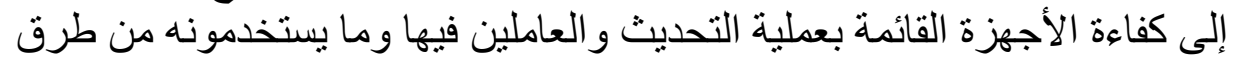

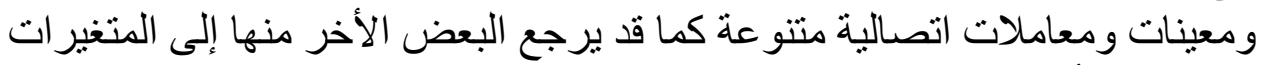

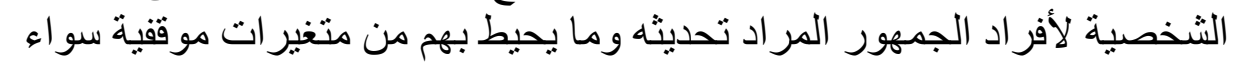

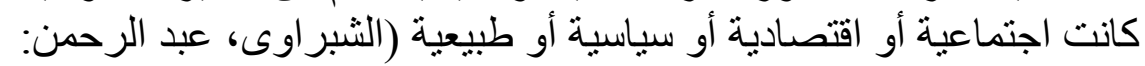

و الجهاز الإرشادي يمثل حلقة الوصل بين الجهات البحثية الزر اعية المختلفة

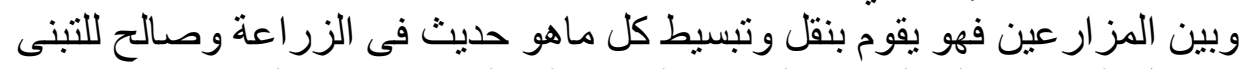

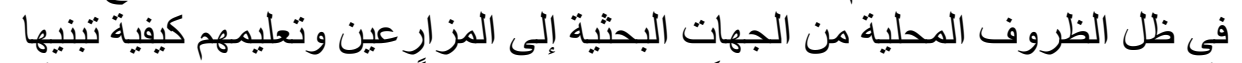

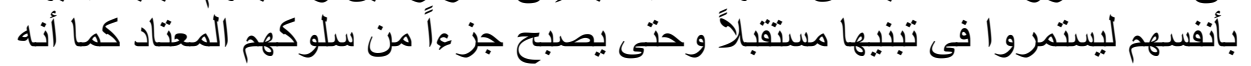

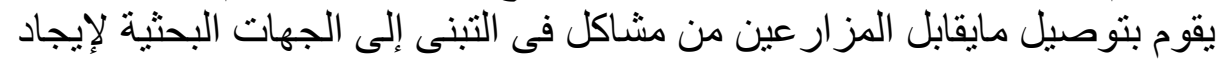

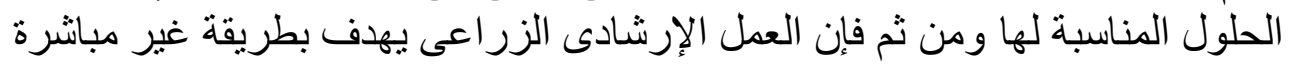

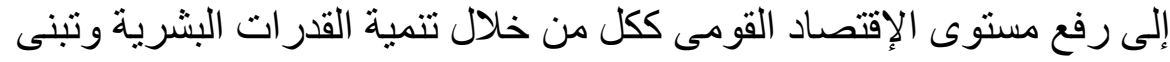

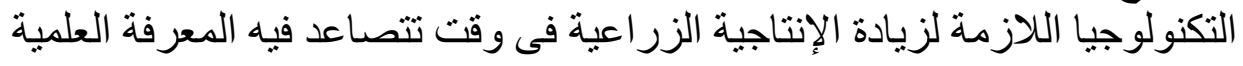

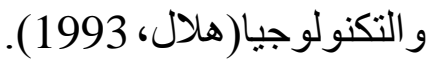

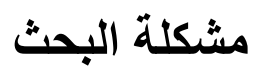

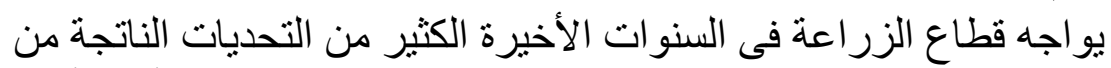

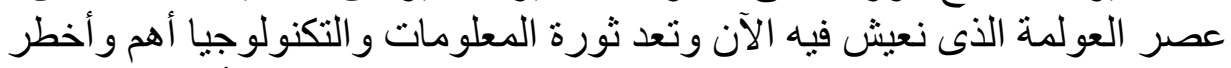

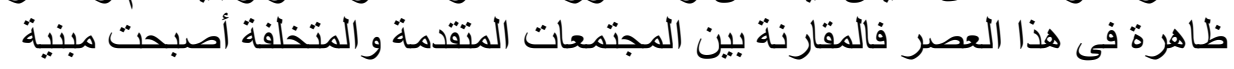
على سر عة تلك المجتمعات فى استخدام وتبنى المعلومات التحات الجديدة و التكنولو جيا الحديثة فى مختلف المجالات.

ولكى يقوم القطاع الزر اعى بدو رهات الطبيعى ويساهم فى عملية التنمية

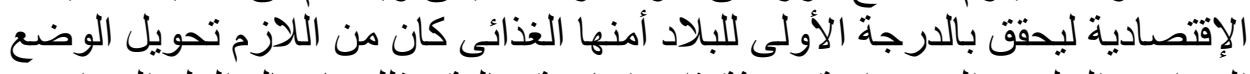

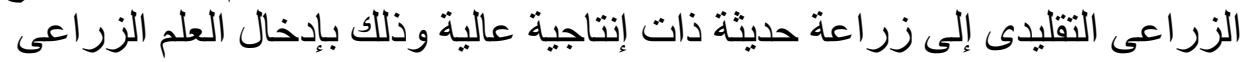

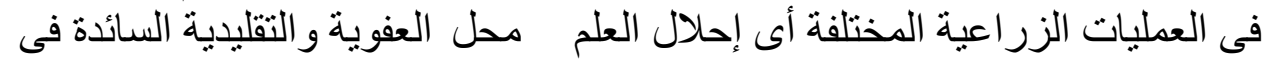

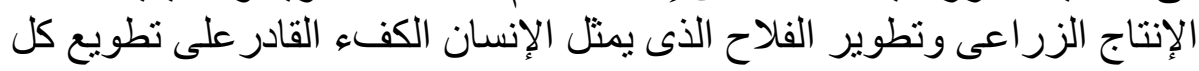

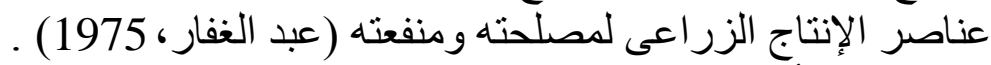

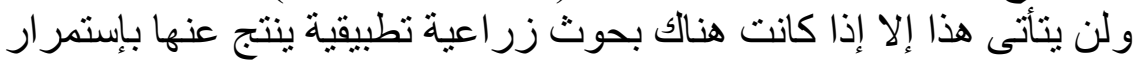

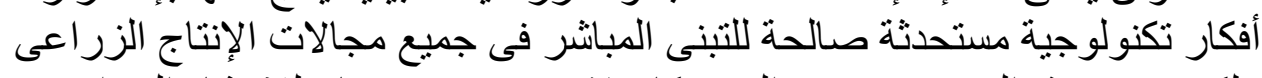
ولكى نضع هذه البحوث موضع التبنى كان لابد من وجود جهاز للإرشاد الزئ الزراعى الزعى 
ذوكفاءة عالية تمكنه من توصيل نتائج تلك البحوث للمز ارعين مع إقناعهم بتنبيها فى (القى

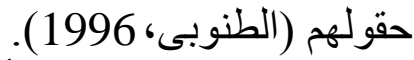

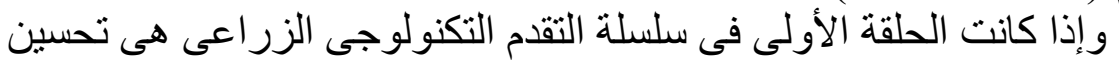

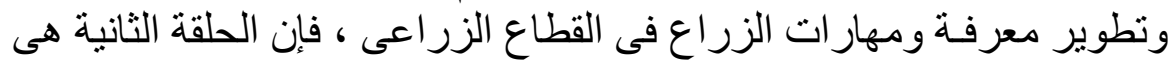

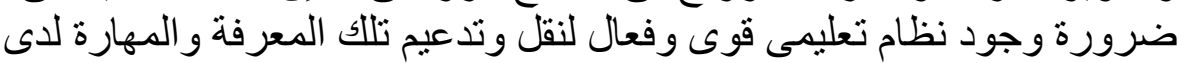

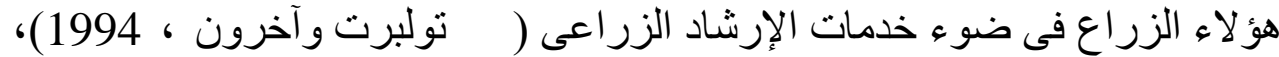

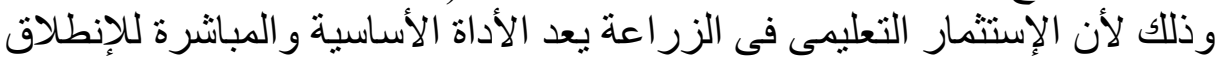

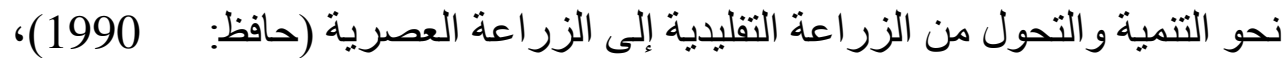

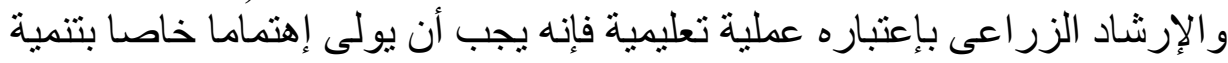

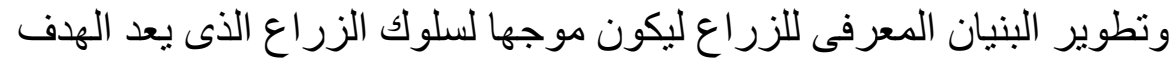

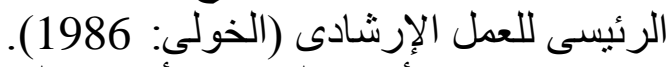

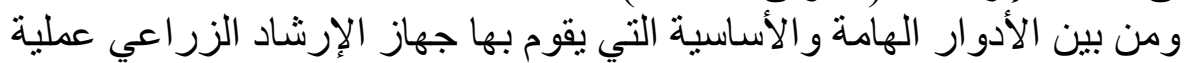

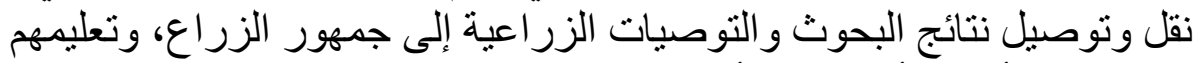

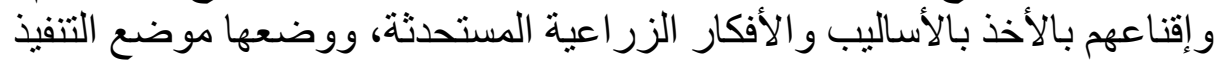

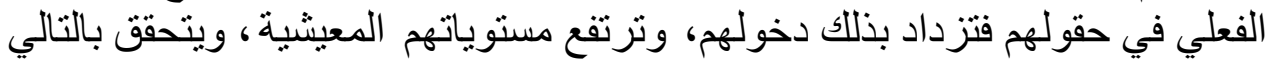

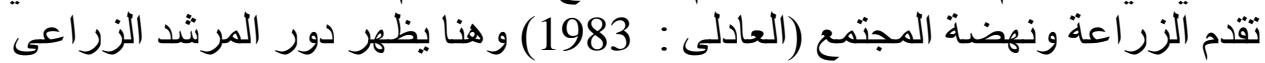

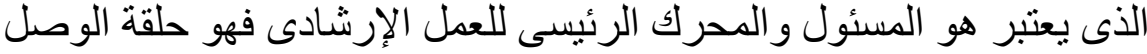

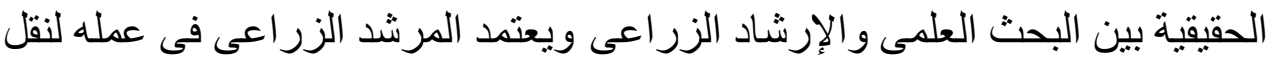

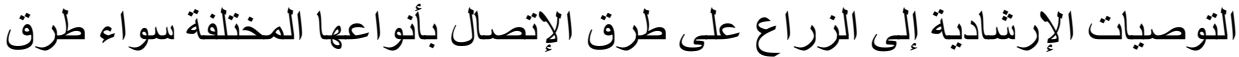

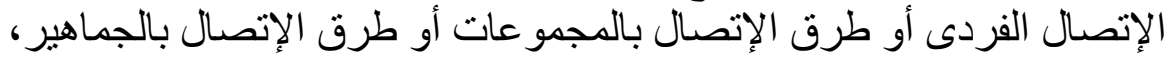

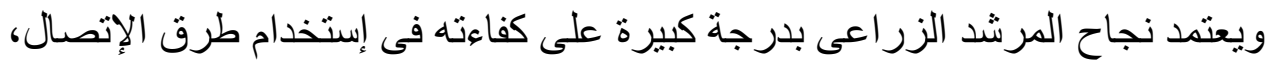

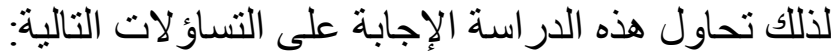

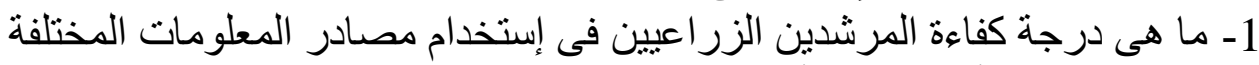

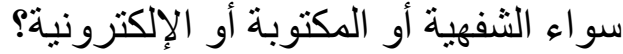

2- ما هى أهم معوقات إستخدام المرشدين لمصادر المعلومات المختلفة؟

1 - التعرف على بعض الخصائص العامة للمرشدين الزر اعيين المبحوثين

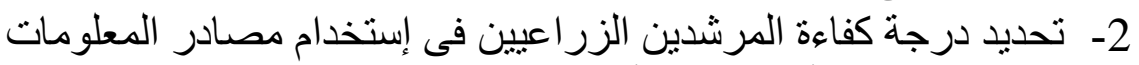

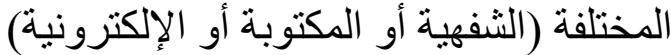

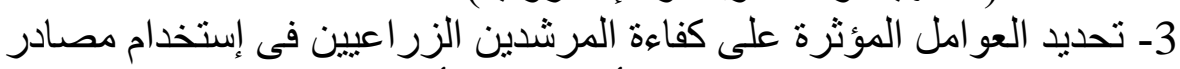

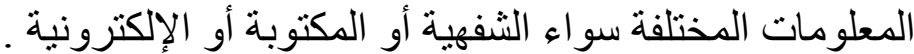

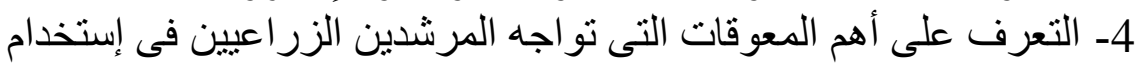
مصادر المعلومات المختلفة . 
5- التعرف على المشكلات التى تو اجه المرشدين الزر اعيين فى مجال العمل بالإرشاد الزر اعى بصفة عامة ومقتر حاتهم لحلها.

الفرض الإحصائى: لاتوجد علاقية إرتباطية بين كفاءة إستخدام المرشدين الزرا اعيين

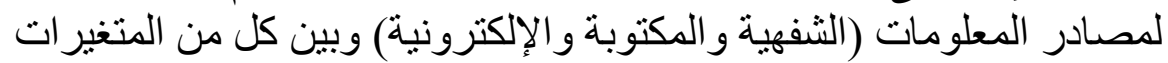

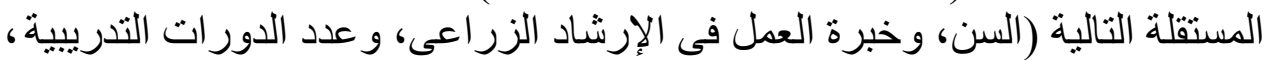

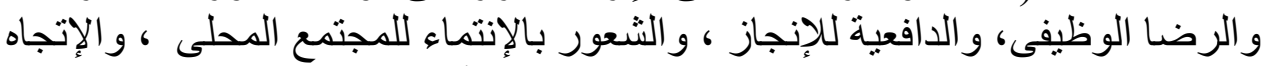

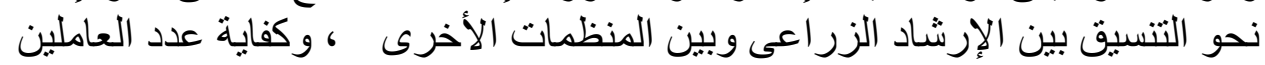
بالمكان، ومناسبة مؤهلات العاملين، و إدر الك العاملين لأهداف الإرشاد الزراعية الزئ. أدوات التحليل الإحصائى: التكرار ات و النسب المئوية والمنتوسط الحسابى ومعامل الإرتباط البسيط لبيرسون.

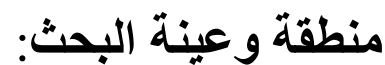

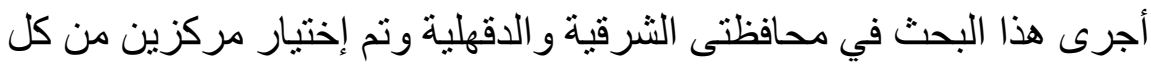

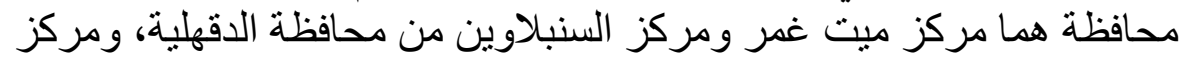

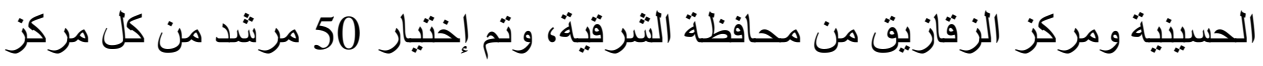

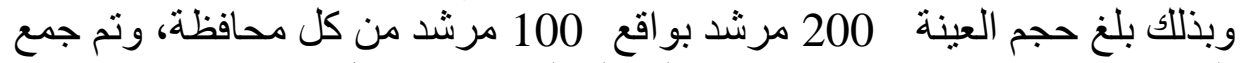
البيانات بإستخدام إستمارة الإستيان بالمقابلة الثخصية خلال عام 2016.

\section{قياس متغيرات البحث:}

أمكن قياس متغير ات البحث على على النحو التالي :

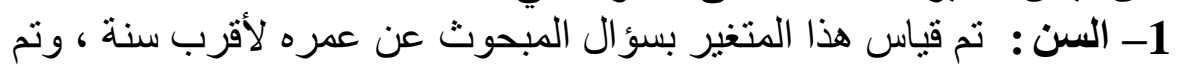

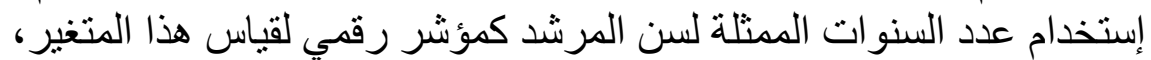

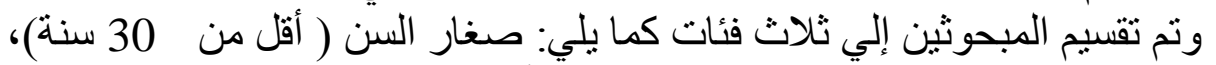

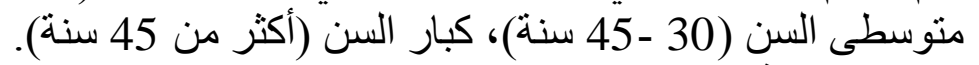

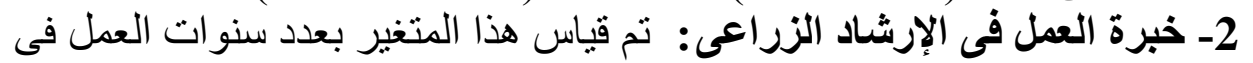

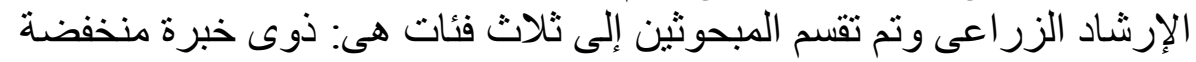

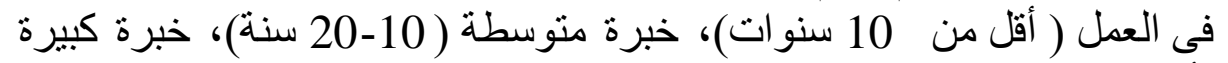
(أكثر من العل 20 سنة).

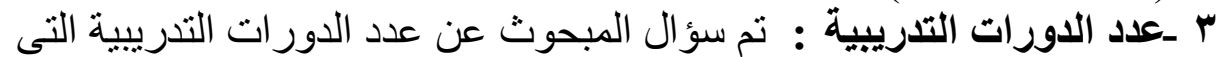

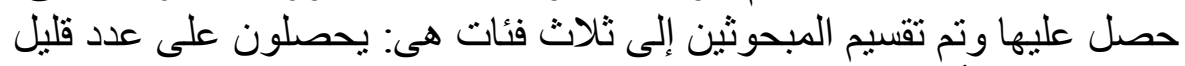

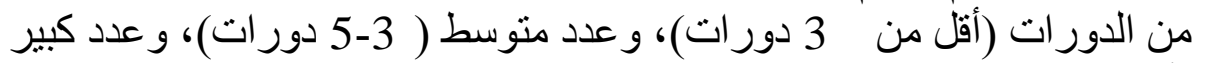

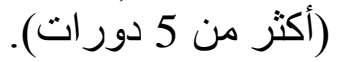




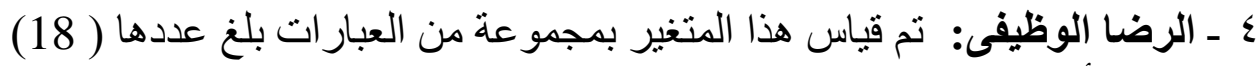

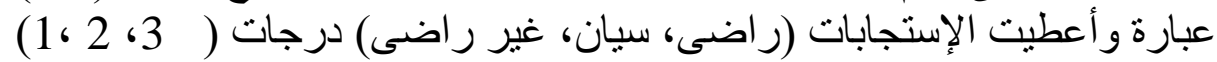

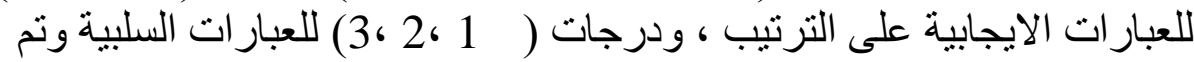

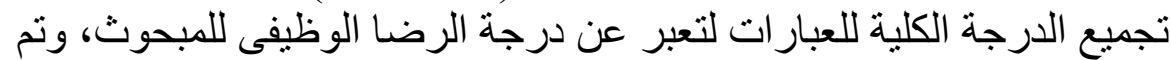

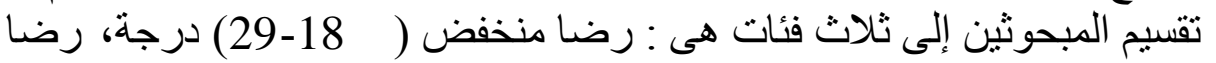

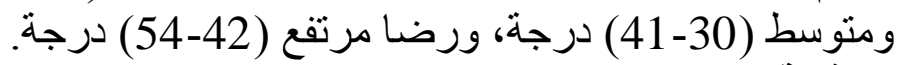

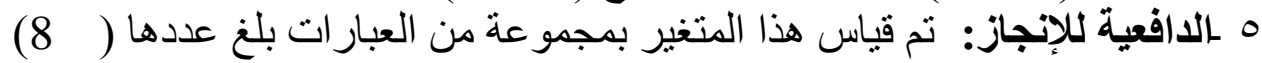

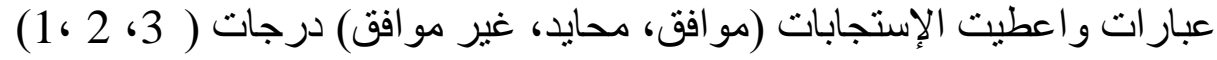

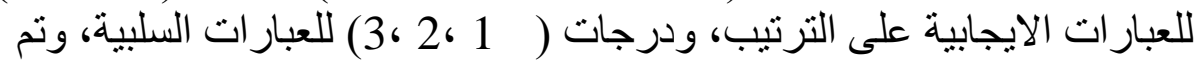

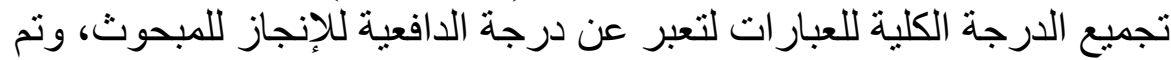

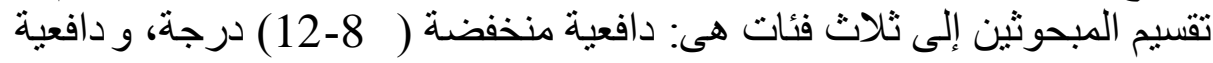

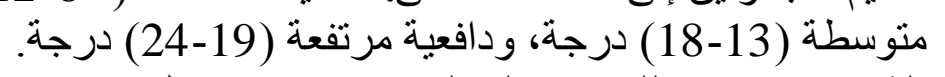

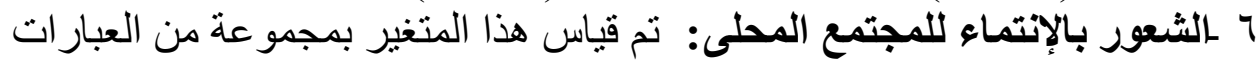

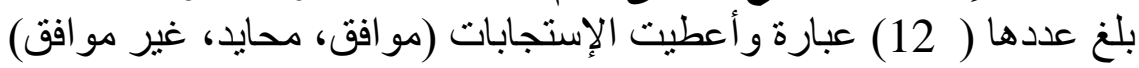

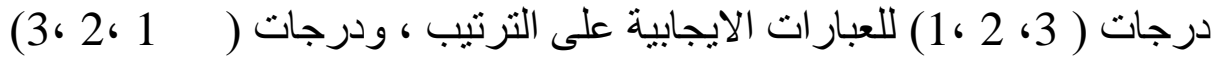

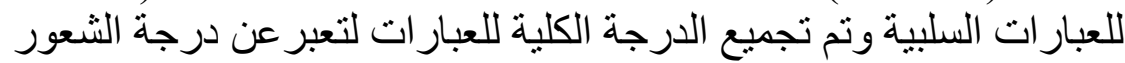

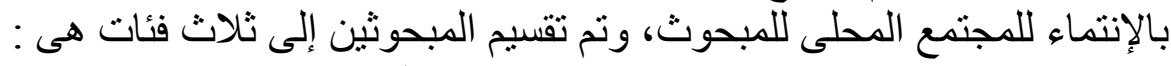

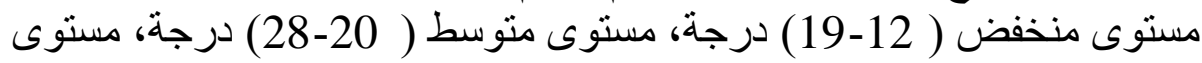

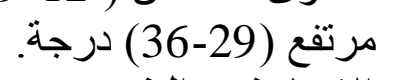

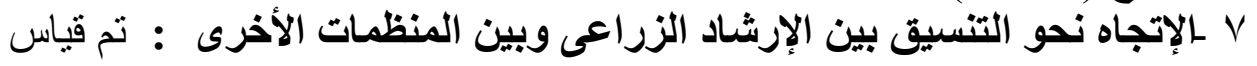

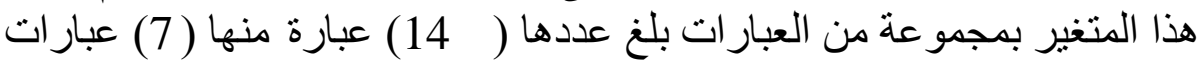

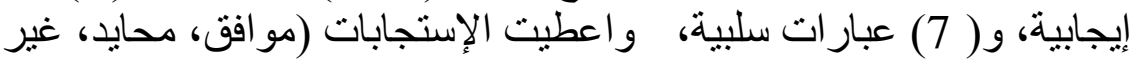

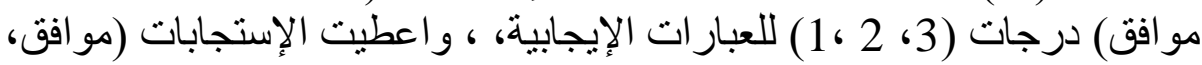

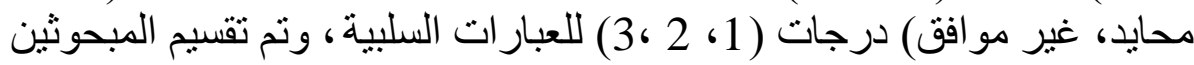

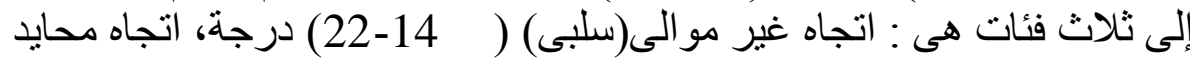

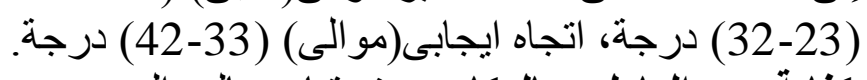

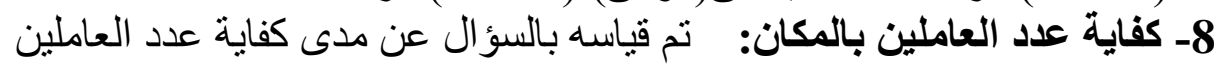

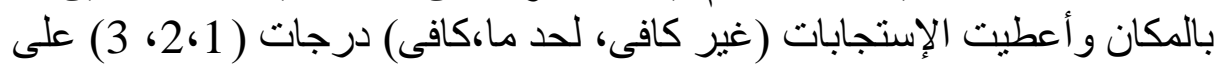

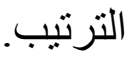
9ـ مناسبة مؤهلات العاملين: نم قياسه بالسؤ ال عن مدى مناسبة مؤهلات العاملين

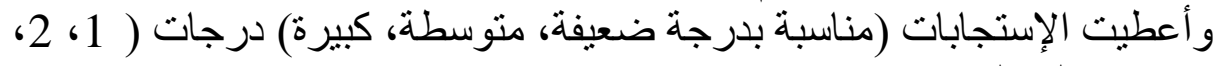

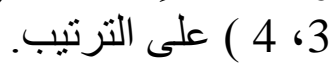


10- إدراك العاملين لأهداف الإرشاد الزراعى: ت تم قياسه بالسؤ ال عن مدى إدراك الك

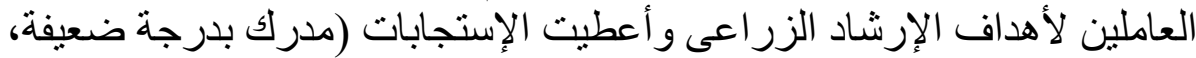

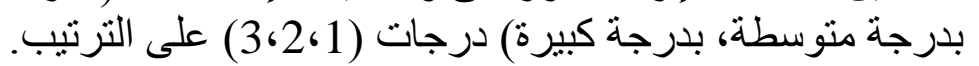

\section{النتائج والمناقشة}

أولا: الخصائص العامة للمبحوثين:

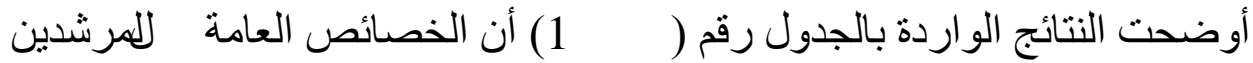
الزر اعبين المبحوثين كانت على النحو النالى:

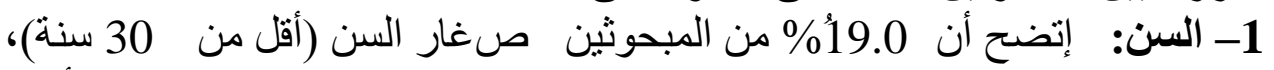
و 52.5\% منهم منوسطى السن (30-45 سنة)، و 28.5\% من منهم كبار السن (أكثر ) من 45 سنة).

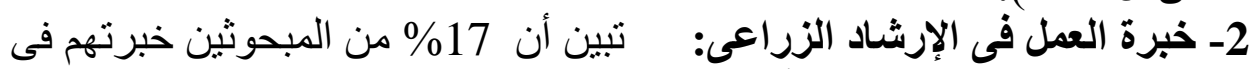

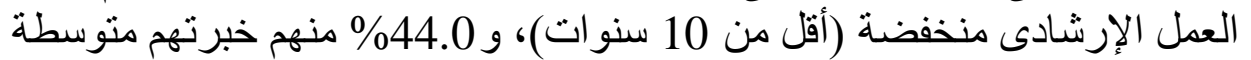
(10-20سنة) و 39.0\% منهم خبرتهم كبيرة (أكثر من 20 سنة منة).

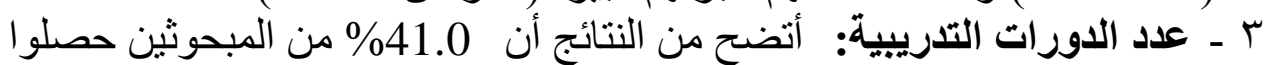

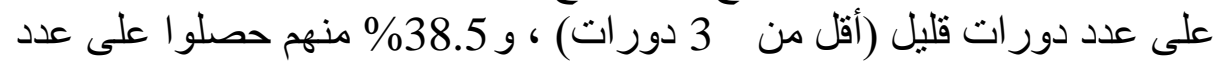

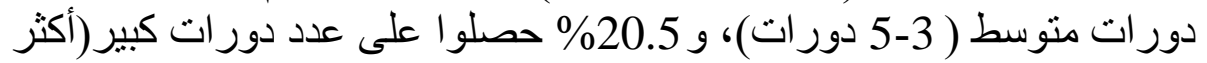

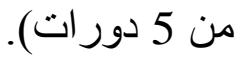

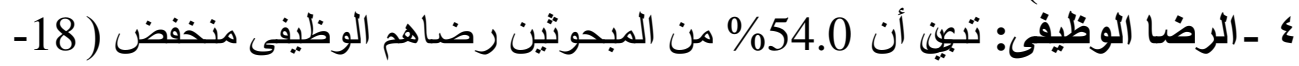

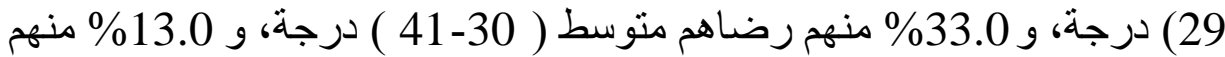
رضاهم مرتفع (42-54) درجة.

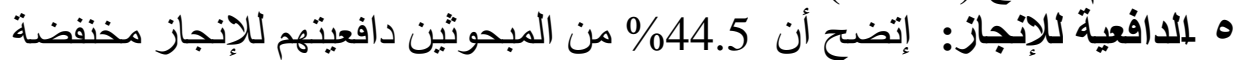

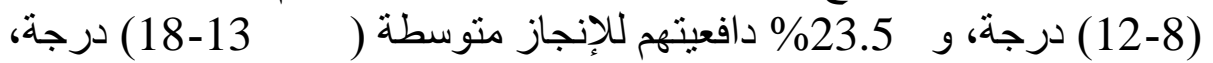

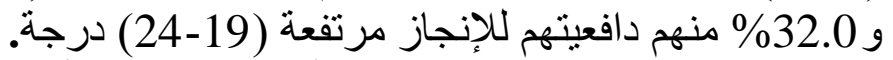

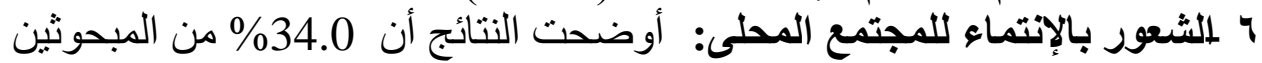

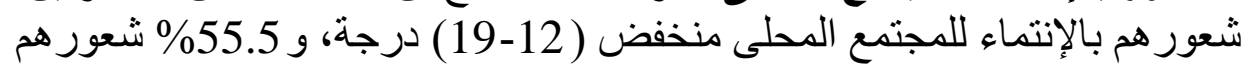
بالإنتماء منوسط (20-28) درجة، و 10.5\% شعور هم بالإنتماء مرتفع (

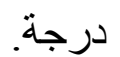

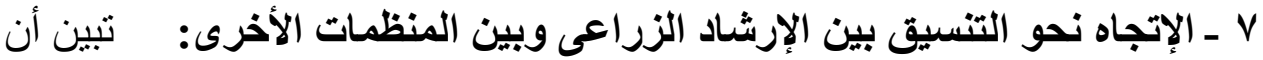

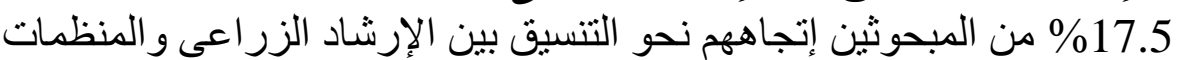

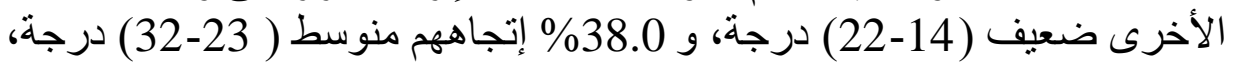
و 44.5\% اتجاه مم قوى (-33-42) درجة. 
جدول رقم (1): الخصائص العامة للمبحوثين

\begin{tabular}{|c|c|c|c|c|c|}
\hline$\%$ & عدلد & المتغيرات & $\%$ & عدد & الكتغيرت \\
\hline \multicolumn{3}{|c|}{ 6- الثُعور بالاتنماء للمجتمع المحلى } & & & 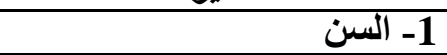 \\
\hline 34.0 & 68 & |شعور منخفض 12-19) درجة & 19.0 & 38 & \\
\hline 55.5 & 111 & شعور متوسط 20-28) درجة & 52.5 & 105 & متوسطى السن(30-45 سنة) \\
\hline 10.5 & 21 & شعور مرتفع (29-36) درجة & 28.5 & 57 & كبار السن (اكثر م54 سنة) \\
\hline \multicolumn{3}{|c|}{ والهنظمات الأخرى التنسيق بين الإششاد الززراعى } & \multicolumn{3}{|r|}{ 2- خبرة العمل فَى الإرشّاد الزراعى } \\
\hline 17.5 & 35 & |اتجاه ضعيف|1-22) درجة & 17.0 & 34 & ة منخ \\
\hline 38.0 & 76 & |اتجاه متوسط332-32) درجة & 44.0 & 88 & خبرة متوسطة 10-20 سنة) \\
\hline 44.5 & 89 & الجاه قوىر(42-3) درجة & 39.0 & 78 & خبرة كبيرة (اكثر ملم20نة) \\
\hline & & 8- كفاية عدد العاملين بالمكان & & & 3- عدد الدورات التدريبية \\
\hline 82.0 & 164 & 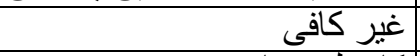 & 41.0 & 82 & عدد قليل (أقل مر3 درورات) \\
\hline 18.0 & 36 & 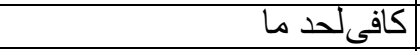 & 38 & 7 & عدد متوسط \$-5 دورات) \\
\hline 0.0 & 0 & كاف & 20.5 & 41 & (اكتُر مرك دورات) \\
\hline & & 9- 9ـاسبة مؤهلات العاملين & & & 4- 4- الرضا \\
\hline 29.0 & 58 & | مناسبة بدرجة ضعيفة & 54.0 & 108 & رضا منخفض 18-29) درجة \\
\hline 32.0 & 64 & مناسبة بذرجة منوسطة & 33.0 & 66 & رضا متوسط(41-31) درجة \\
\hline 32.0 & 64 & |مناسبة بذرجة كبيرة & 13.0 & 26 & رضا مرتفع (42-54) درجة \\
\hline 7.0 & 14 & | غير مناسبة & & & 5- الدافعية للإنجاز \\
\hline 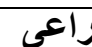 & شُداد & 13- إداركك العاملين لأهداف & 44.5 & 9 & دافعية منخفضة|8(-12) درجة \\
\hline 19.5 & 39 & | مدركبدرجة ضعيفة & 23 & 47 & دافعية منوسطة (18-18) درجاً \\
\hline 38.5 & 77 & مدركبدرجة متوسطة & 32.0 & 64 & دافعية مرتفعةو1-24) درجة \\
\hline 42.0 & 84 & | مدركبدرجة كبيرة & & & \\
\hline
\end{tabular}

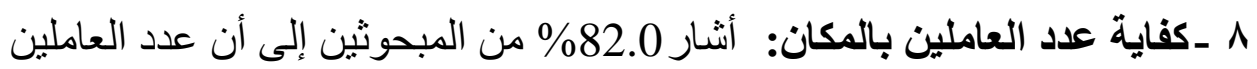

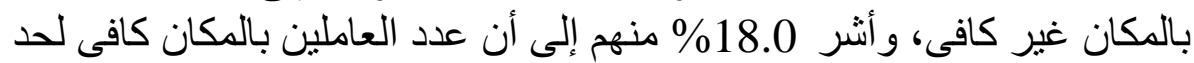

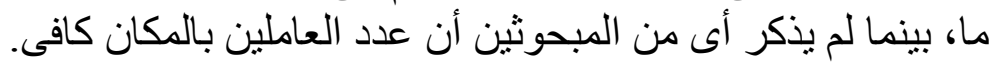

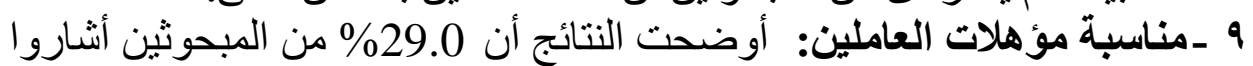

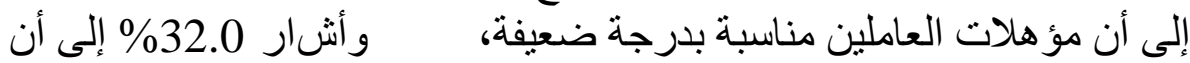

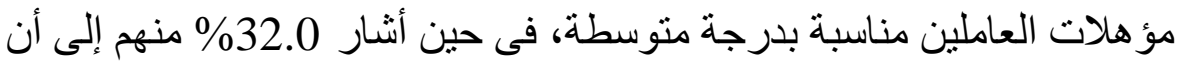

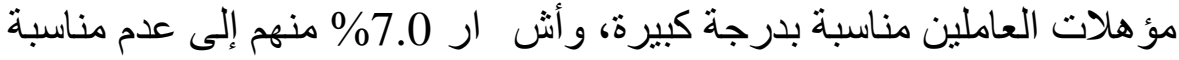
مؤهلات العاملين فى الإرشاد الزارين الزاعى.

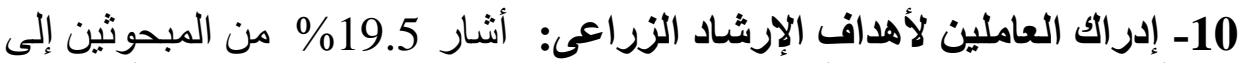

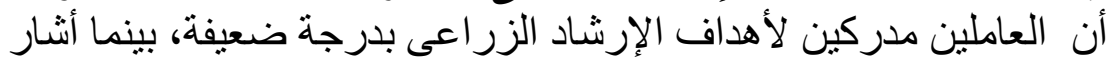

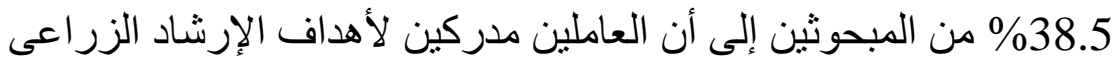

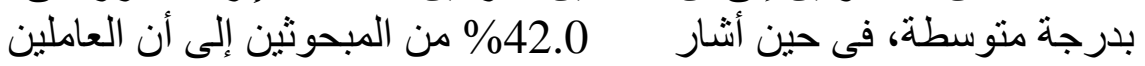

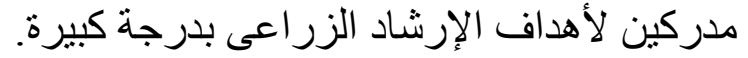


ثنانيا: كفاءة المرشدين الزراعيين المبحوثين في إستخدام مصادر المعلومات المختلفة (الثفهية أو المكتوبة أو الإكترونية):

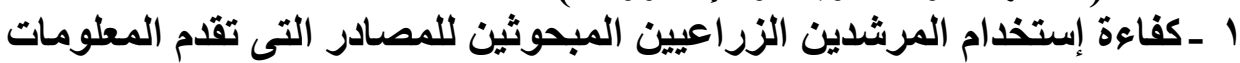
في صوره شفهية:

أوضحت النتائج الوردة بالجدول رقم (2

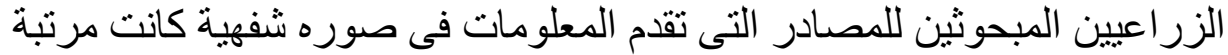

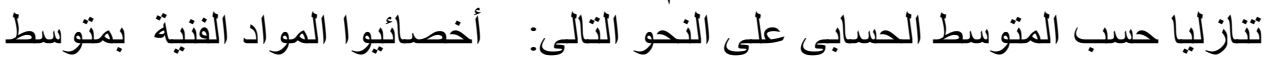

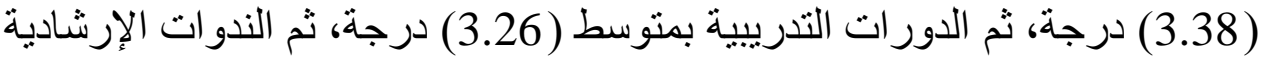

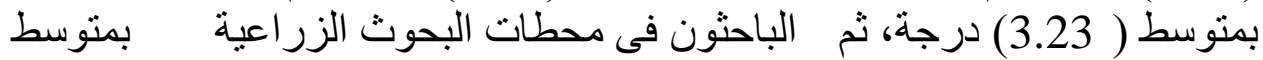

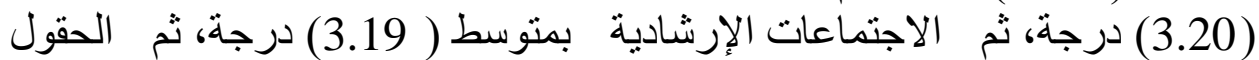

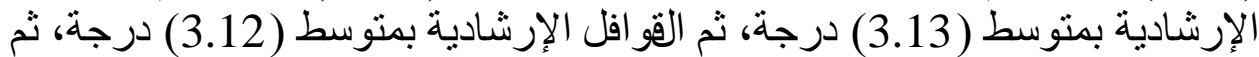

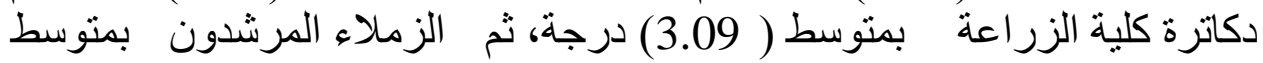

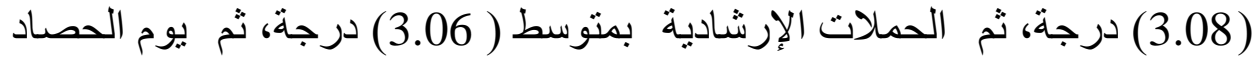

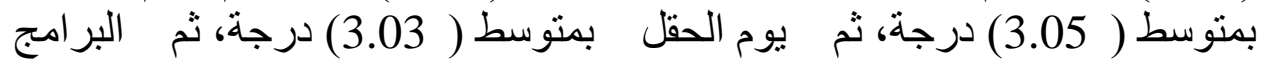
التليفزيونية الزر اعية بمنوسط (3.70) درجة درجة.

جدول رقم ( 2): كفاءة إستخدام المرشدين الزر اعيين المبحوثين للمصادر التى تقدم المعلومات فى صوره شفئية المرنية

\begin{tabular}{|c|c|c|c|c|c|c|c|c|c|c|}
\hline الحستابى & \multicolumn{2}{|c|}{ أستخذمها } & \multicolumn{2}{|c|}{ ضرجيفة } & \multicolumn{2}{|c|}{ متوسطة } & \multicolumn{2}{|c|}{ كلرجيزة } & المصادر & $?$ \\
\hline 338 & 135 & 27 & 55 & 11 & 11 & 22 & 70 & 140 & |خصيائيو المواد & 1 \\
\hline & & & & & & & & & 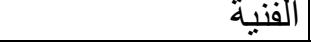 & \\
\hline & 4.5 & 9 & 18.5 & 37 & 24 & 48 & 53 & 106 & الدورات التدريبية & 2 \\
\hline & 8.5 & 17 & 15.5 & 31 & 21 & $\frac{42}{30}$ & 55 & 110 & 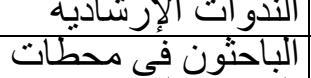 & $\begin{array}{r}3 \\
4\end{array}$ \\
\hline 20 & 11 & 22 & 14 & 28 & 19.5 & 39 & 55.5 & 111 & البحوثت الزر اعية & \\
\hline 3.19 & 7 & 14 & 18 & 36 & 24 & 48 & 51 & 102 & | الا جنما & $J$ \\
\hline 3.13 & 0 & 0 & 27 & 54 & 33.5 & 67 & 39.5 & 79 & الحَقوَل ألإرشادية & 6 \\
\hline 3.12 & 4 & 8 & 23.5 & 47 & 29 & 58 & 43.5 & 87 & |القو افل الإرشادية & 7 \\
\hline & 6.5 & 13 & 22 & 44 & 27.5 & 55 & 44 & 88 & دكاترة كلية الزر اعة & \\
\hline & 20.5 & 41 & 8.5 & 17 & 14 & 28 & 57 & 114 & الزملاء المرشدون & 9 \\
\hline 3.06 & 18.5 & 37 & 11 & 22 & 16.5 & 33 & 54 & 108 & الحملات الإرشادية & 10 \\
\hline & 17.5 & 35 & 12.5 & 25 & 18 & 36 & 52 & 104 & يو الحصاد & \\
\hline & 5.5 & 11 & 25 & 50 & 30.5 & 61 & 39 & 78 & إيوم الحقل & 12 \\
\hline 2.70 & 39 & 78 & 4 & 8 & 5.5 & 11 & 51.5 & 103 & الالبر امبجة التليفزيونية & \\
\hline
\end{tabular}

المصدر: جمعت وحسبت من بيانات الدراسة الميدانية بمحافظتى الثرقية و الدقهلية، 2016. 
2-كفاءة إستخدام المرشدين الزراعيين المبحوثين للمصادر التى تقدم المعلومات فى صوره مكتوبة:

أوضحت النتائج الواردة بالجدول رقم ( ) 3) أن كفاءة إستخدام المرشدين

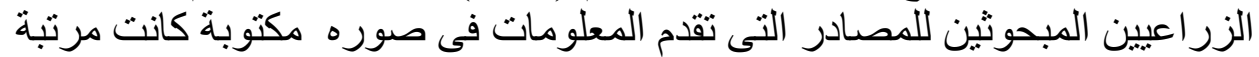

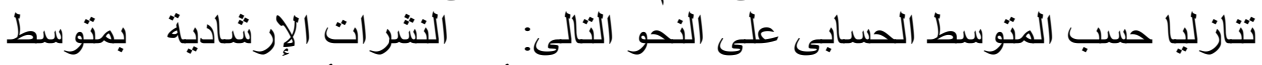
(3.29) درجة ، ثم تعليمات من الإدارة الزر اعية أو المديرية أو الوزارة الإلهابة

جدول رقم ( 3): كفاءة إستخدام المرشدين الزر اعيين المبحوثين للمصادر التى تقدم

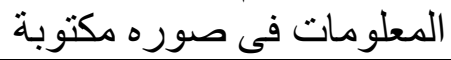

\begin{tabular}{|c|c|c|c|c|c|c|c|c|c|c|}
\hline \multirow{2}{*}{ الحسابى } & \multicolumn{2}{|c|}{ لا أستخذمها } & \multicolumn{2}{|c|}{ درجة ضعيفةٌ } & \multicolumn{2}{|c|}{ درجة متوسطة } & \multicolumn{2}{|c|}{ درجة كبيرة } & \multirow{2}{*}{ المصادر } & \multirow[t]{2}{*}{ P } \\
\hline & $\%$ & عدد & $\%$ & عدد & $\%$ & عدد & $\%$ & عدد & & \\
\hline 3.29 & 3 & 6 & 12 & 24 & 38.5 & 77 & 46.5 & 93 & النشرات الإرشاديةً & $\mathbf{1}$ \\
\hline 3.16 & 6.5 & 13 & 15.5 & 31 & 34 & 68 & 44 & 88 & أو الزراعية أو المديرية الإدارة & 2 \\
\hline 3.11 & 7.5 & 15 & 15.5 & 31 & 35.5 & 71 & 41.5 & 83 & تقتاريز وتعليمات الرؤساء & 3 \\
\hline 3.06 & 8.5 & 17 & 18 & 36 & 32.5 & 65 & 41 & 82 & الزجلة الإرشاد & 4 \\
\hline 3.05 & 10.5 & 21 & 17.5 & 35 & 29 & 58 & 43 & 86 & الملصقات & 5 \\
\hline 2.98 & 12 & 24 & 19 & 38 & 28 & 56 & 41 & 82 & مطبوعات التدريب & 6 \\
\hline 2.83 & 13.5 & 27 & 30.5 & 61 & 16 & 32 & 40 & 80 & الكتب و المراجع & 7 \\
\hline 2.70 & 21 & 42 & 24 & 48 & 19.5 & 39 & 35.5 & 71 & الآبحاث العلمية & 8 \\
\hline
\end{tabular}

بمتوسط (3.16) درجة، ثم تقارير وتعليمات مكتوبة من الرؤساء بمتوسط (3.11)

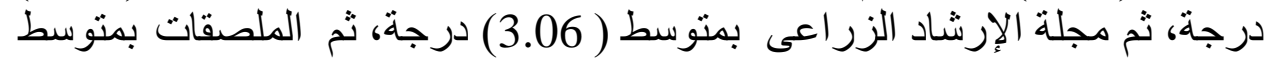

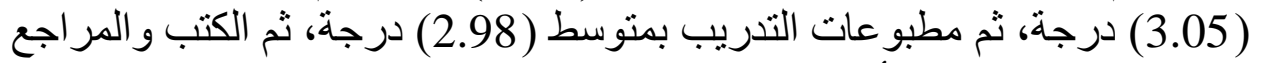
بمتوسط (2.83) ، ثم الأبحاث العلمية بمتوسط (2.70) درجة.

3-كفاءة إستخدام المرشدين الزراعيين المبحوثين لمصادر المعلومات الإكترونية:

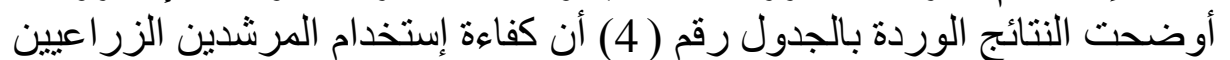

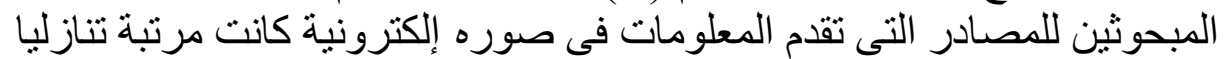

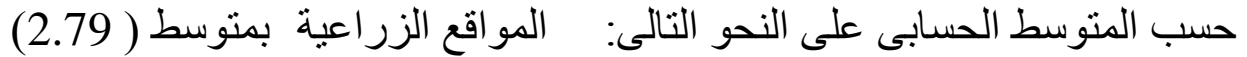
درجة، ثم الفيسبوك بمتوسط ( 2.66) درجة، ثم النظم الخبيرة بمتوسط (2.56)

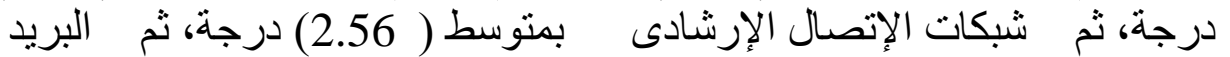
الإلكترونى بمنوسط (2.55) درجة، ثم الإنترنت بمنتوسط (2.48) درجة. 
جدول رقم (4): كفاءة إستخدام المرشدين الزر اعيين المبحوثين لمصادر المعلومات

\begin{tabular}{|c|c|c|c|c|c|c|c|c|c|c|}
\hline \multirow{2}{*}{ المتوسط } & \multicolumn{2}{|c|}{ لا أستخدمها } & \multicolumn{2}{|c|}{ درجة ضعيفة } & \multicolumn{2}{|c|}{ درجة متوسطة } & \multicolumn{2}{|c|}{ درجة كبيرة } & \multirow{2}{*}{ المصادر } & \multirow[t]{2}{*}{ r } \\
\hline & $\%$ & عداد & $\%$ & عدد & $\%$ & عدد & $\%$ & عدد & & \\
\hline 2.79 & 18 & 36 & 17 & 34 & 33.5 & 67 & 31.5 & 63 & الزراعية & 1 \\
\hline 2.66 & 21.5 & 43 & 20.5 & 41 & 29 & 58 & 29 & 58 & الفيسبوك & 2 \\
\hline 2.56 & 22.5 & 45 & 25.5 & 51 & 25.5 & 51 & 26.5 & 53 & النظم الخبيرة & 3 \\
\hline 2.56 & 23.5 & 47 & 23 & 46 & 27.5 & 55 & 26 & 52 & الإنشادل & 4 \\
\hline 2.55 & 25.5 & 51 & 22.5 & 45 & 24 & 48 & 28 & 56 & الإلبكترونى & 5 \\
\hline 2.48 & 27 & 54 & 24 & 48 & 23 & 46 & 26 & 52 & الإنترنت & 6 \\
\hline
\end{tabular}

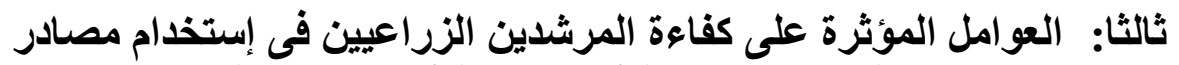

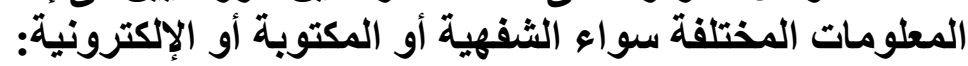

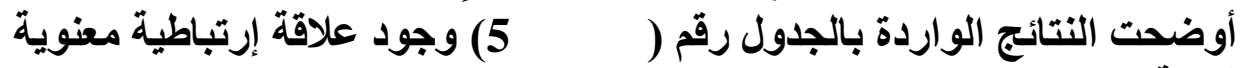

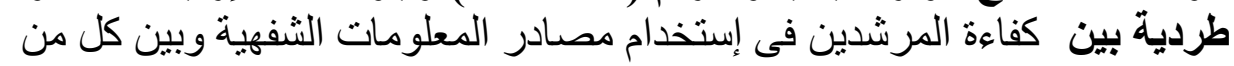

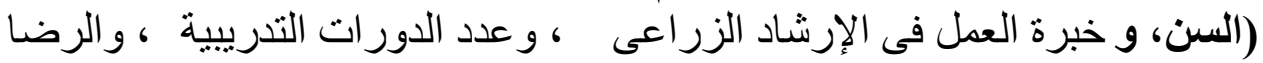

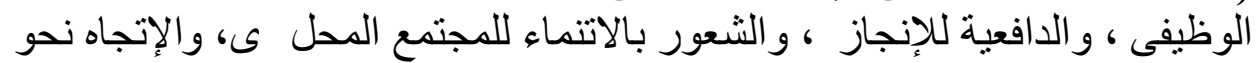

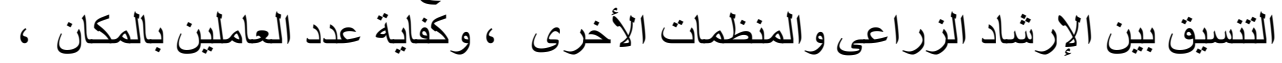

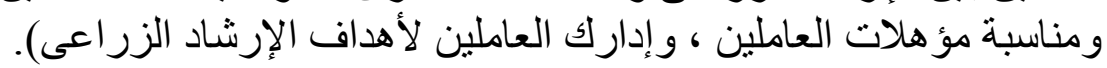


كما أوضحت النتائج الواردة بنفس الجدول وجود علاقة إرتباطية معنوية طردية

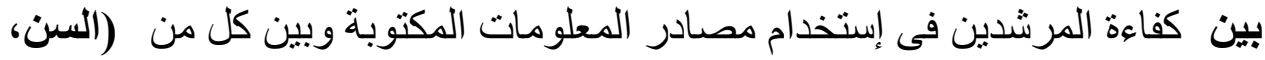

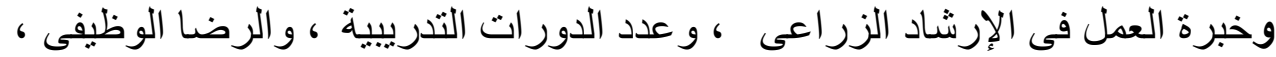

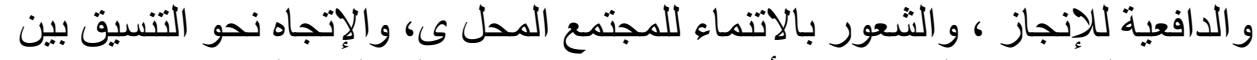

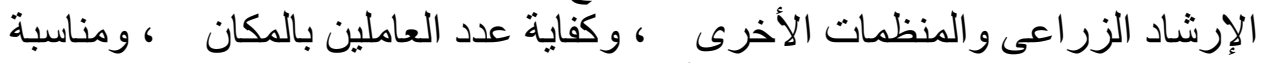
مؤهلات العاملين ، و إدارك العاملين لأهداف الإرشاد الزئ الزراعى).

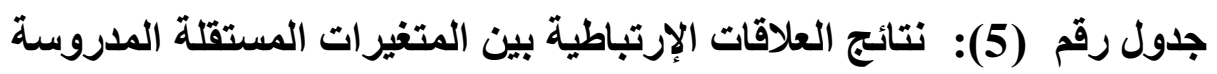

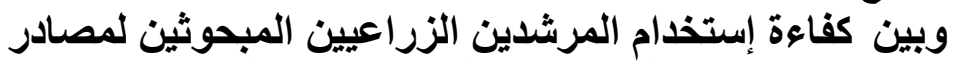

المطلومات (الثفهية، والمكتوبة، والمينة الإكترونية)

\begin{tabular}{|c|c|c|c|}
\hline كفاءة إستخد الم مصادر & كفاءة إستخدام مصادر & مصادرة المعلومات & المتغيرات المستقلة \\
\hline$-0.628^{* *}$ & $0.480^{* *}$ & $0.586^{* *}$ & مس \\
\hline 0.181 & $0.398 * *$ & $0.469 * *$ & خبرة العمل فى الإرشاد الزراعى \\
\hline $0.717 * *$ & $0.706^{* *}$ & $0.803^{* *}$ & عدد الدورات التدريبية \\
\hline $0.953^{* *}$ & $0.385^{* *}$ & $0.834 * *$ & الرضا الوظيفى \\
\hline $0.452 * *$ & $0.652^{* *}$ & $0.712 * *$ & لافعية للإنجاز \\
\hline $00.622 * *$ & $0.394 * *$ & $0.697 * *$ & الثعور بالاتنماء للمجتمع المحلى \\
\hline $00.702 * *$ & $0.455^{* *}$ & $0.774 * *$ & 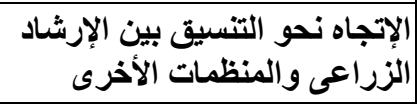 \\
\hline $0.672 * *$ & $0.501 * *$ & $0.757 * *$ & كفاية عدد العاملين بالمكان \\
\hline $0.413 * *$ & $0.672 * *$ & $0.687 * *$ & مناسبة مؤهلات العاملين \\
\hline $0.687 * *$ & $0.757^{* *}$ & $0.575^{* *}$ & |إدارك العاملين لأهداف الإرشاد \\
\hline
\end{tabular}

المصدر: جمعت وحسبت من بيانات الدراسة الميدانية بمحافظنى الثرقية و الدقهلية، 2016.

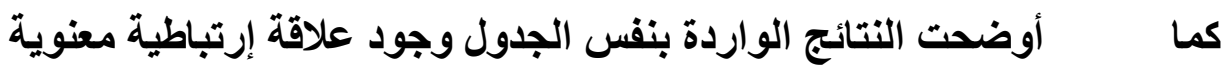

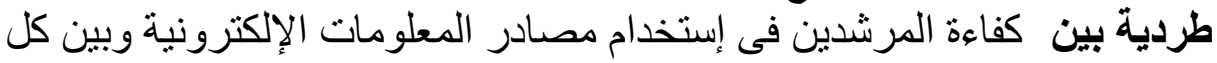

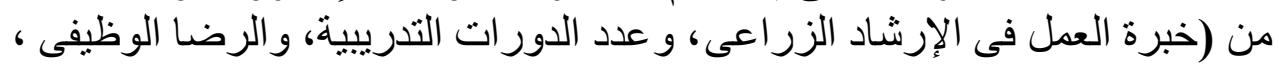

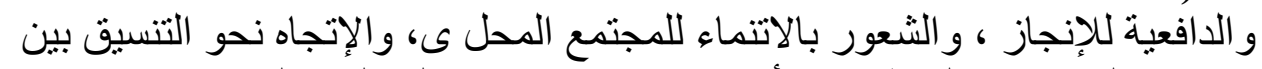

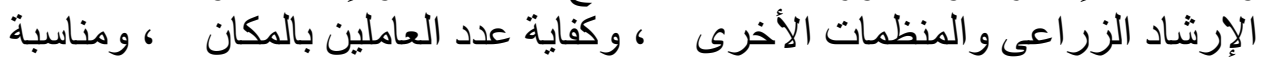

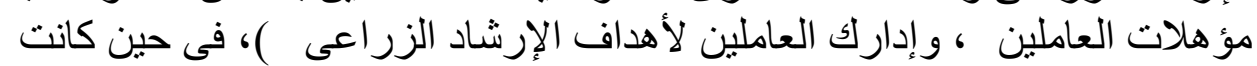
العلاقة عكسية مع السن، ولم تتأكد المعنوية الإحصائية للعلاقة مع الثاعت الثعور بالإنتماء للمجتمع المحلى. 
رابعا: المعوقات التي تواجه المرشدين الزراعين في إستخدام مصادر المعلومات إلمختلفة

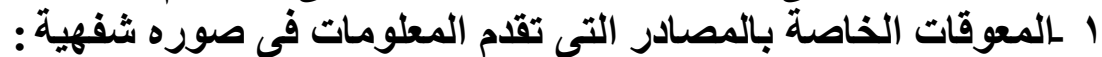

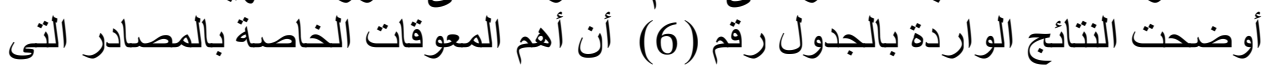

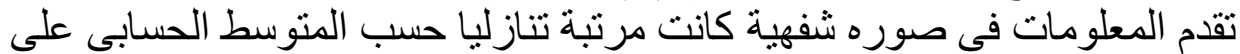

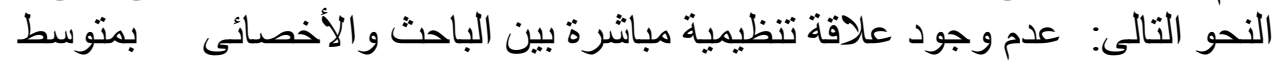

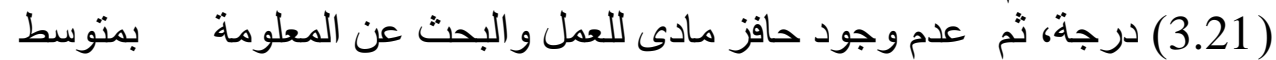

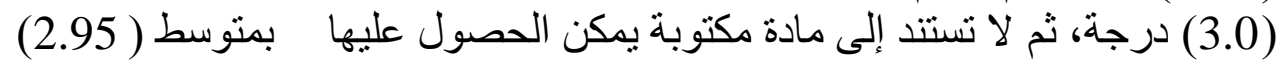

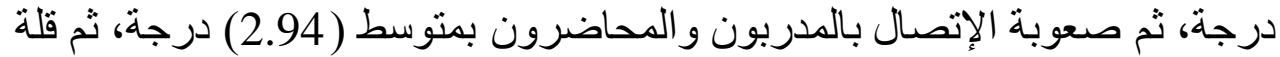

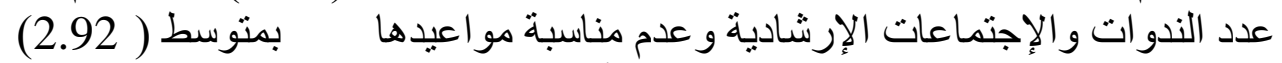

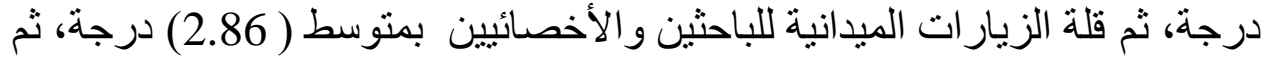

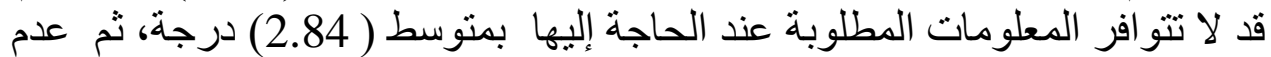

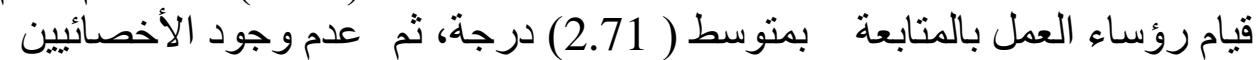

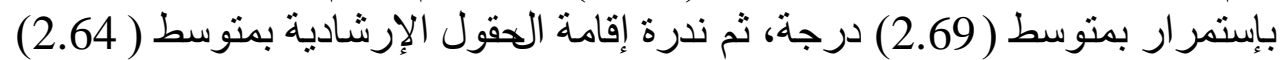

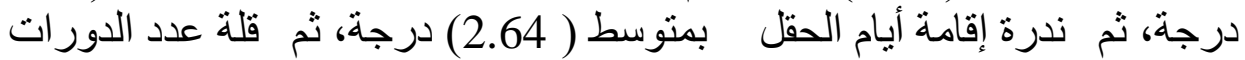

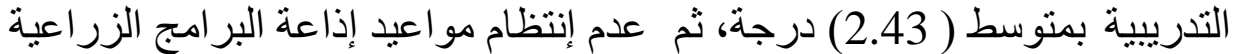

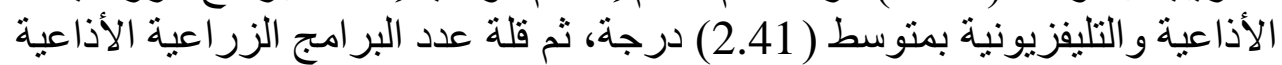

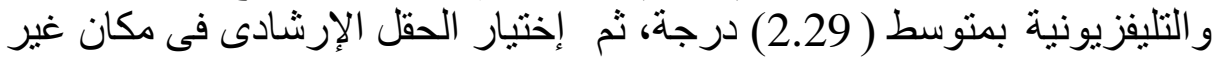

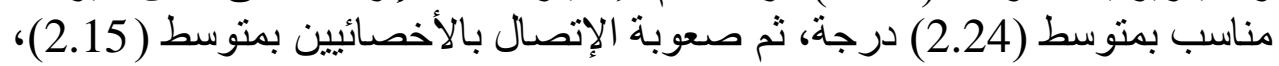
ثم ندرة إقامة يوم الحصاد بمتوسط (2.10) درجة دمة دمة

r ـالمعوقات الخاصة بالمصادر التى تقدم المعلومات فى صوره مكتوبة :

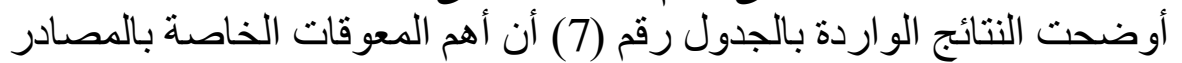

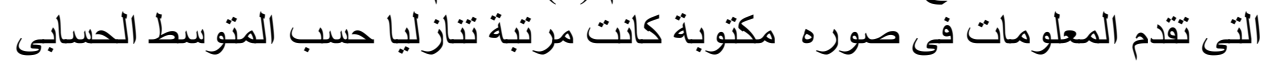
على النحو التالى: قلة عدد النشرات الإرشادية بمتوسط (3.21) درجة، ثم قلة عدد

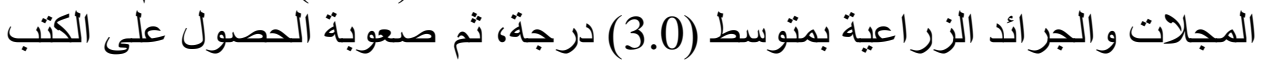

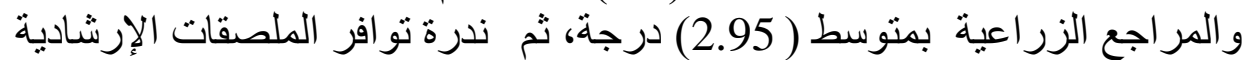

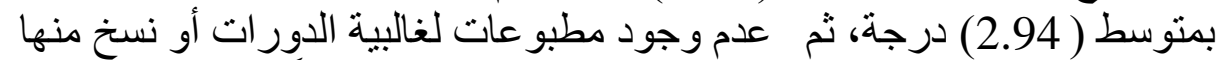

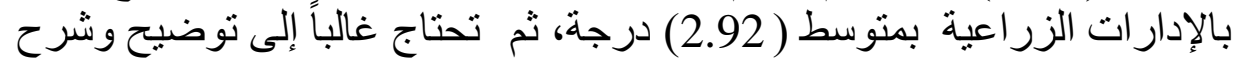

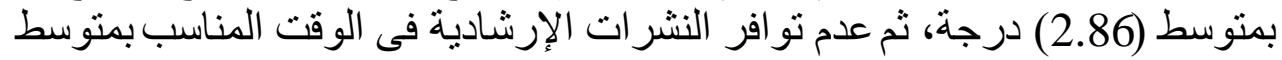

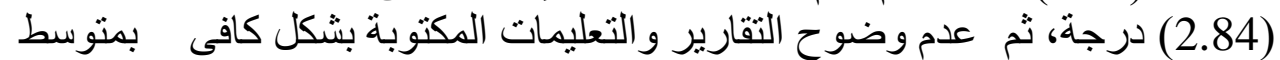

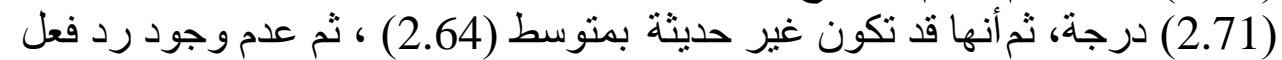

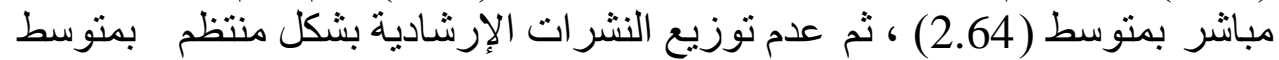

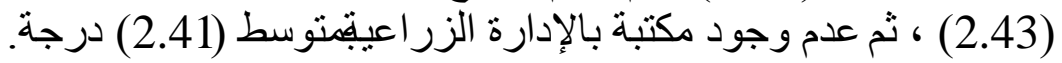


جدول رقم (6): المعوقات الخاصة بالمصادر التى تقدم المعلومات فى صوره شفهية

\begin{tabular}{|c|c|c|c|c|c|c|c|c|c|c|}
\hline \multirow{2}{*}{ الحسابى المسط } & \multicolumn{2}{|c|}{ لا أستخدمها } & \multicolumn{2}{|c|}{ درجة ضعيفة } & \multicolumn{2}{|c|}{ |دتوسطة } & \multicolumn{2}{|c|}{ درجة كبيرة } & \multirow[t]{2}{*}{ المصادر } & \multirow[t]{2}{*}{ p } \\
\hline & $\%$ & عدد & $\%$ & عدد & $\%$ & عدد & $\%$ & عدد & & \\
\hline 3.21 & 6.0 & 12 & 16.5 & 33 & 28.5 & 57 & 49.0 & 98 & 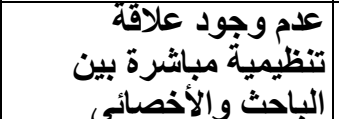 & 1 \\
\hline 3.00 & 9.5 & 19 & 24.5 & 49 & 22.5 & 45 & 43.5 & 87 & اللعملم والبحثث عافز من مادى & 2 \\
\hline 2.95 & 15.0 & 30 & 20.5 & 41 & 19.0 & 38 & 45.5 & 91 & |لا تستنا إلى مادة مكتوية & 3 \\
\hline 2.94 & 15.0 & 30 & 20.5 & 41 & 20.5 & 41 & 44.0 & 88 & |بالمدربونة الإتصال والمحاضرون & 4 \\
\hline 2.92 & 15.0 & 30 & 19.5 & 39 & 24.0 & 48 & 41.5 & 83 & 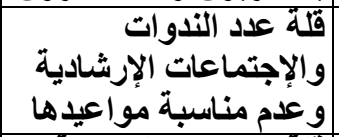 & 5 \\
\hline 2.86 & 19.5 & 39 & 19.0 & 38 & 18.0 & 36 & 43.5 & 87 & للباحثين الزيارات الأخصائيينية & 6 \\
\hline 2.84 & 17.0 & 34 & 25.0 & 50 & 15.5 & 31 & 42.5 & 85 & 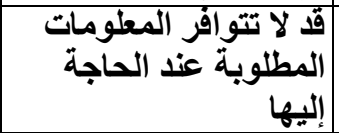 & 7 \\
\hline 2.71 & 29.0 & 58 & 13.5 & 27 & 15.5 & 31 & 42.0 & 84 & بالمتابعة قيام رؤساء العمل & 8 \\
\hline 2.69 & 23.5 & 47 & 22.5 & 45 & 16.0 & 32 & 38.0 & 76 & بإستمرار & 9 \\
\hline 2.64 & 28.0 & 56 & 17.5 & 35 & 17.5 & 35 & 37.0 & 74 & |لندرة إقُامة $\quad$ الحقول & 10 \\
\hline 2.64 & 29.5 & 59 & 16.0 & 32 & 15.5 & 31 & 39.0 & 78 & ندرة إقامة أيام الحقل & 11 \\
\hline 2.43 & 41.0 & 82 & 10.5 & 21 & 13.5 & 27 & 35.0 & 70 & |لتذريبية الدورات & 12 \\
\hline 2.41 & 43.5 & 87 & 9.0 & 18 & 11.0 & 22 & 36.5 & 73 & 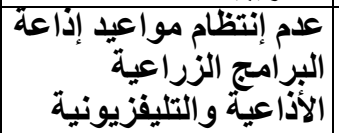 & 13 \\
\hline 2.29 & 41.5 & 83 & 17.0 & 34 & 13.0 & 26 & 28.5 & 57 & | التزراعية الأبراعية & 14 \\
\hline 2.24 & 47.5 & 95 & 12.0 & 24 & 9.5 & 19 & 31.0 & 62 & |فِّى مكان غيّل الإرشبادى & 15 \\
\hline 2.15 & 33.5 & 67 & 37.5 & 75 & 9.5 & 19 & 19.5 & 39 & بالأخصوبة الإتصالين & 16 \\
\hline 2.10 & 46.5 & 93 & 18.5 & 37 & 13.5 & 27 & 21.5 & 43 & |ندرة إقامة يوم الحصاد & 17 \\
\hline
\end{tabular}


جدول رقم (7): المعوقات الخاصة بالمصادر التى تقدم المعلومات فى صوره مكتوبة

\begin{tabular}{|c|c|c|c|c|c|c|c|c|c|c|}
\hline \multirow{2}{*}{ الحسابى المط } & \multicolumn{2}{|c|}{ لا أستخدمها } & \multicolumn{2}{|c|}{ |درجةٌ ضعيفةٌ } & \multicolumn{2}{|c|}{ درجة متوسطة } & \multicolumn{2}{|c|}{ درجة كبيرة } & \multirow{2}{*}{ المصادر } & \\
\hline & $\%$ & عدد & $\%$ & عدد & $\%$ & عدد & $\%$ & عدد & & \\
\hline 3.21 & 6.0 & 12 & 16.5 & 33 & 28.5 & 57 & 49.0 & 98 & |قلة عدد النشرات & \\
\hline 3.00 & 9.5 & 19 & 24.5 & 49 & 22.5 & 45 & 43.5 & 87 & |قالة عدد المجلات & 2 \\
\hline 2.95 & 15.0 & 30 & 20.5 & 41 & 19.0 & 38 & 45.5 & 91 & |الكتب والمراجع الحصول على & \\
\hline 2.94 & 15.0 & 30 & 20.5 & 41 & 20.5 & 41 & 44.0 & 88 & |ندرة توافر الملصقات & 4 \\
\hline 2.92 & 15.0 & 30 & 19.5 & 39 & 24.0 & 48 & 41.5 & 83 & لغالبية الدورات الوبات أو نسيخّ & $J$ \\
\hline 2.86 & 19.5 & 39 & 19.0 & 38 & 18.0 & 36 & 43.5 & 87 & توشترح غالباً إلى توضيح & 6 \\
\hline 2.84 & 17.0 & 34 & 25.0 & 50 & 15.5 & 31 & 42.5 & 85 & فلى الوقت توافر النشراسب الإرشا & 7 \\
\hline 2.71 & 29.0 & 58 & 13.5 & 27 & 15.5 & 31 & 42.0 & 84 & | بلثك وضليمات المكتوبة التقاريز & 8 \\
\hline 2.64 & 28.0 & 56 & 17.5 & 35 & 17.5 & 35 & 37.0 & 74 & قا تكون غير حديثة & 9 \\
\hline 2.64 & 29.5 & 59 & 16.0 & 32 & 15.5 & 31 & 39.0 & 78 & عدم وجود ردفعل مباشر & 10 \\
\hline 2.43 & 41.0 & 82 & 10.5 & 21 & 13.5 & 27 & 35.0 & 70 & الإرشادية بشكل منتظم النشر ات & 11 \\
\hline 2.41 & 43.5 & 87 & 9.0 & 18 & 11.0 & 22 & 36.5 & 73 & | الزراعية وجود مكتبة بالإدارة & 12 \\
\hline
\end{tabular}

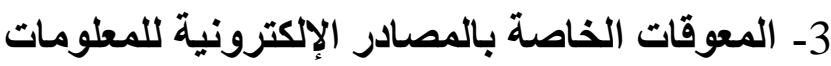

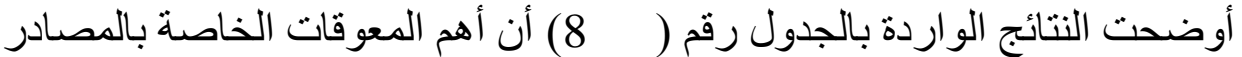

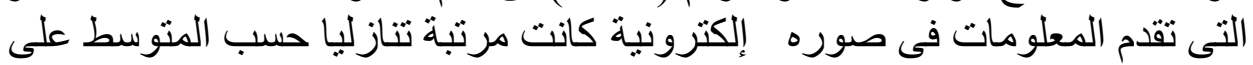

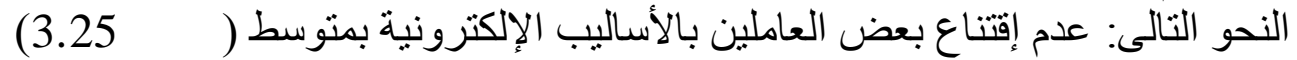

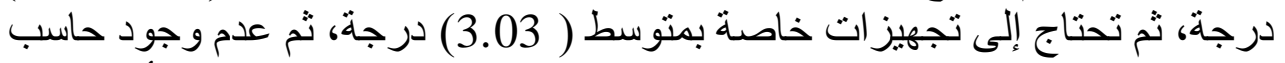

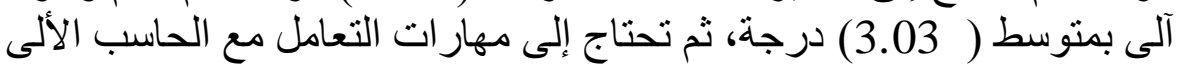

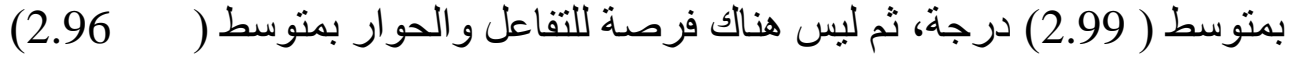

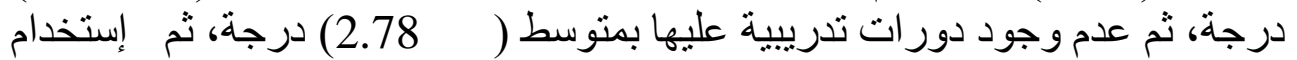

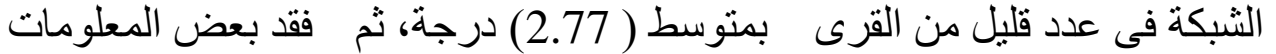
الإرشادية نتيجة تعرضها للفيروسات بمتوس سط (2.68) درجة. 
جدول رقم (8): المعوقات الخاصة بالمصادر الإلكترونية للمعلومات .

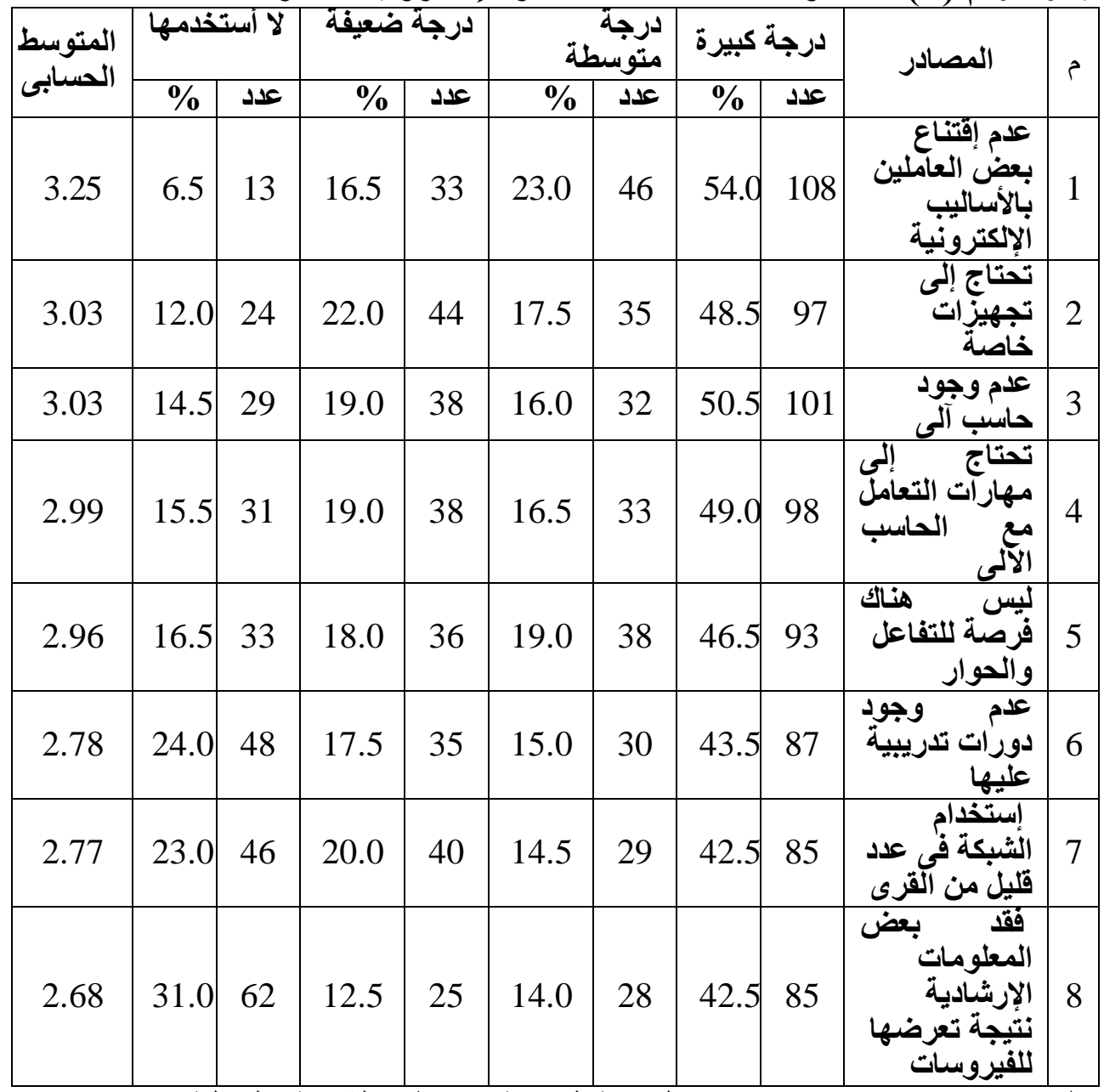

المصدر: جمعت وحسبت من بيانات الدر اسة الميدانية بمحافظتى الثرقية و الدقهلية، 2016.

خامسا : المشكلات التى تواجه المرشدين الزراعيين المبحوثين فى مجال العمل

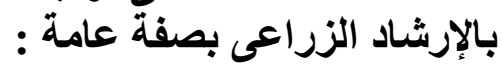

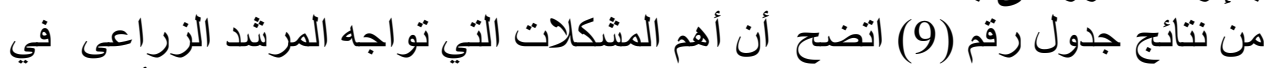

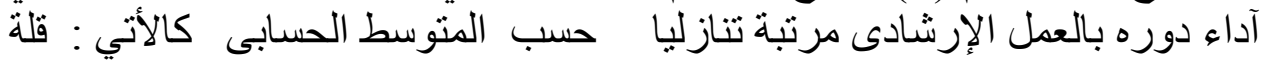

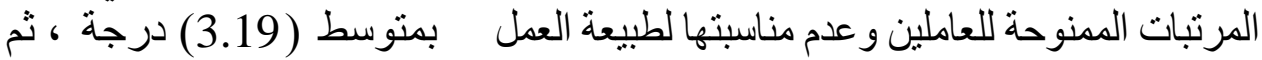

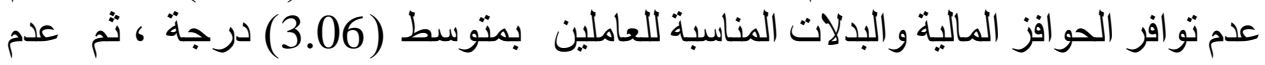

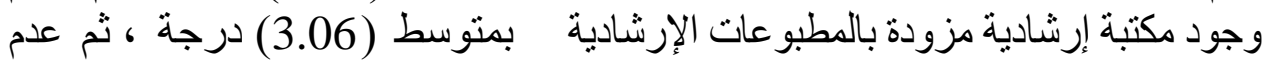

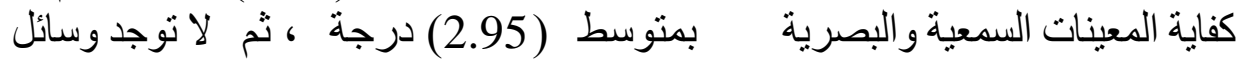
مواصلات لخدمة العاملين بمتوسط (2.94) درجة ، ثم عدم كفاية الميزانية التى دئى 
جدول رقم (9): المشكلات التى تواجه المرشدين المبحوثين فى مجال العمل

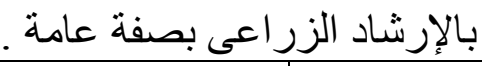

\begin{tabular}{|c|c|c|c|c|c|c|c|c|c|c|}
\hline \multirow{3}{*}{ الحسابى } & \multicolumn{8}{|c|}{ لدرجة وجودها } & \multirow{3}{*}{ المشكلات } & \multirow{3}{*}{$p$} \\
\hline & \multicolumn{2}{|c|}{ موجوية } & \multicolumn{2}{|c|}{ ضبرجفة } & \multicolumn{2}{|c|}{ متضوسطة } & \multirow{2}{*}{\multicolumn{2}{|c|}{ كبلرجة }} & & \\
\hline & $\%$ & عداد & $\%$ & عدد | ع إ & $\%$ & عدد | (2) & & عدد" & & \\
\hline 3.19 & 8.0 & 16 & 15.5 & 31 & 26.0 & 52 & 50.5 & 101 & 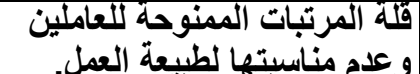 & 1 \\
\hline 3.06 & 10.0 & 20 & 19.5 & 39 & 25.5 & 51 & 45.0 & 90 & 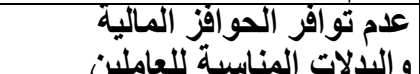 & 2 \\
\hline 3.06 & 10.0 & 20 & 19.5 & 39 & 25.5 & 51 & 45.0 & 90 & 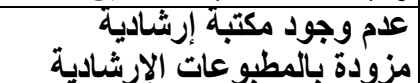 & 3 \\
\hline 2.95 & 15.0 & 30 & 22.0 & 44 & 16.0 & 32 & 47.0 & 94 & و العصر كفاية المعينات السمعية & 4 \\
\hline 2.94 & 15.5 & 31 & 21.0 & 42 & 18.0 & 36 & 45.5 & 91 & لالاتئنج. وسائل مواصلات لذامة & 5 \\
\hline 2.91 & 17.5 & 35 & 19.5 & 39 & 18.0 & 36 & 45.0 & 90 & الحكومة كفةية الميزانية التى تقلمها & 6 \\
\hline 2.90 & 17.5 & 35 & 19.0 & 38 & 19.5 & 39 & 44.0 & 88 & للإتصام توفر الخبّرات الماتحة اللازمة & 7 \\
\hline 2.88 & 17.5 & 35 & 20.5 & 41 & 19.0 & 38 & 43.0 & 86 & 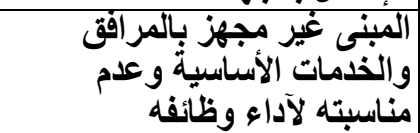 & 8 \\
\hline 2.73 & 21.5 & 43 & 24.0 & 48 & 15.0 & 30 & 39.5 & 79 & القنص الإمكانيات البشرية من & 9 \\
\hline 2.73 & 23.5 & 47 & 21.0 & 42 & 15.0 & 30 & 40.5 & 81 & نقص الإعداد و التّريب للعامليز & \\
\hline
\end{tabular}

تقدمها الحكومة بمتوسط (2.91)، ثم عدم توفر الخبرات اللازمة للإتصال بالجهات المانحة بمتوسط (2.90) درجة ، ثم المبنى غير مجهز بالمر افق والق والخدمات الأساسية

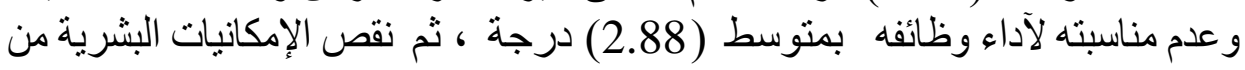

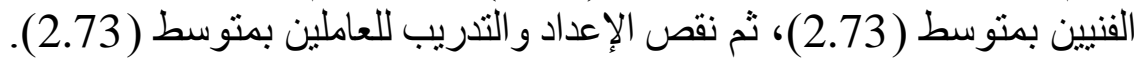

سادسا : مقترحات المرشدين المبحوثين للتظلب على المشكلات التى تواجههم فى

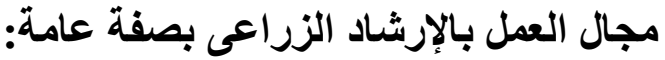

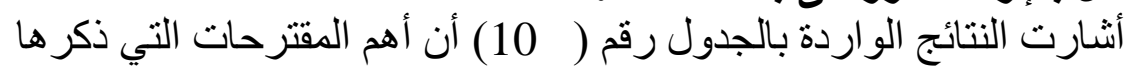

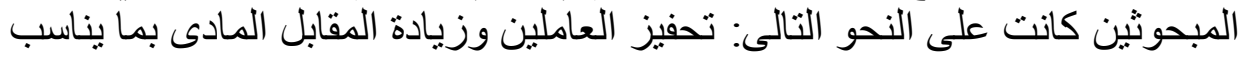

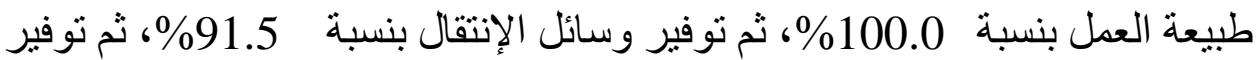

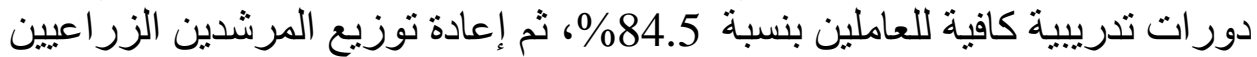

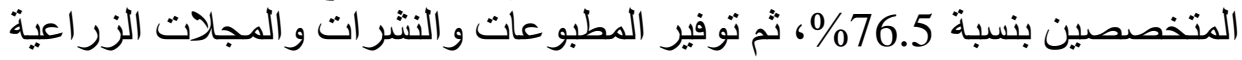




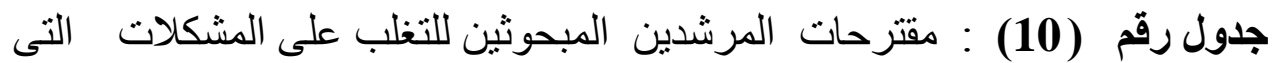

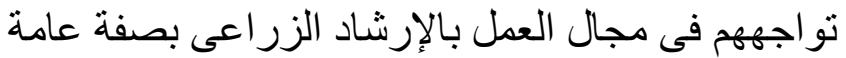

\begin{tabular}{|c|c|c|c|}
\hline$\%$ & 18 & 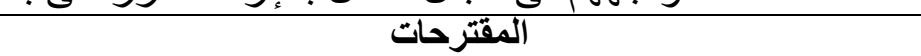 & \\
\hline 100.0 & 00 & تحفيز العاملين وزيادة المقابل المادى بما يناسب طبيعة العمل & \\
\hline & & توفير وسائل الإنتقال & \\
\hline 84.5 & 69 & توفير دور ات تدريبية كافية للعاملين & \\
\hline 76 & 15 & إعادة توزيع المرشّدين الزراعيين المتخصصين & \\
\hline 76 & 153 & 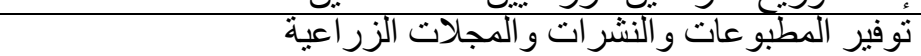 & \\
\hline 50 & & إستخدام مرشدين متخصصبن في ألبرامج الإرشادية & \\
\hline 44 & 89 & أُستخدام مرشدين متخصصين في الطرق و المعينات الإرشادية & \\
\hline 35.5 & 71 & إستخدام مرشدين متخصصين فى تكنولوجيا المعلومات و الإتصال & \\
\hline 32. & 64 & ألتوصيف الوظيفى لمهام وواجبات المرشد المتخصص & \\
\hline 30 & 61 & تتظيم العلاقة الرسمية مع الجهات البحثيّة الزراعية فى المنطقة & 1 \\
\hline 21. & 42 & تتظيج العلاقة الرسمية مع الكنظمات المحلية الحكومية و غير الحكومية بالمة & \\
\hline & 35 & تدريب القادة المحليين من الزراع & 12 \\
\hline 18 & 36 & توفير الدعم المالى لإقامة الندوات & 4 \\
\hline 17 & 34 & إستخدام مرشدين متخصصين فى الإقتصاد المنزلى & 14 \\
\hline 11.0 & 22 & توفير حقول إرشادية & 15 \\
\hline 9.0 & 18 & إستكمال الاجهزة ووسائل الإتصال & 10 \\
\hline 7.0 & 14 & توفير التمويل اللاززم لصبانة المبانى والاجهزة والمعدات & 17 \\
\hline
\end{tabular}

بنسبة \% 76.5\%، ثم إستخدام مرشدين متخصصين فى البر امج الإرشادية بنسبة

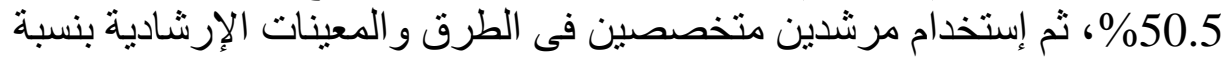

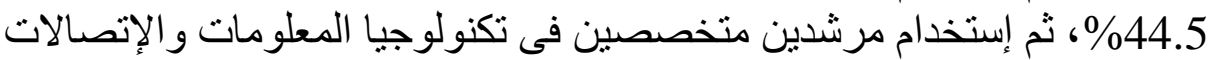

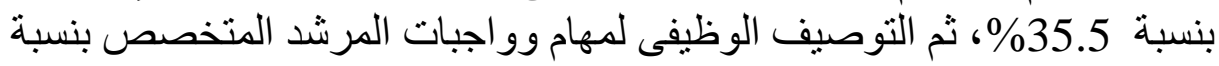

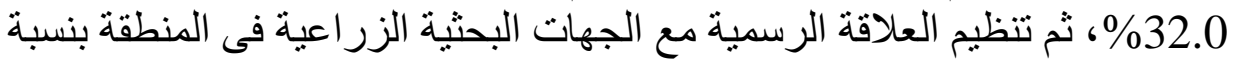

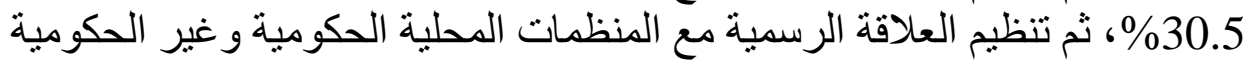

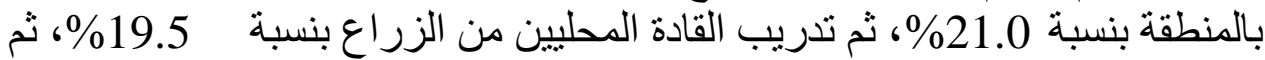

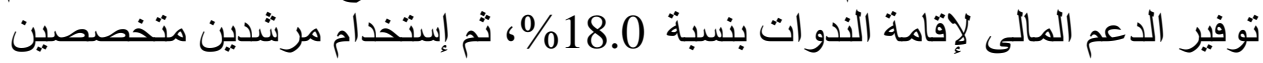

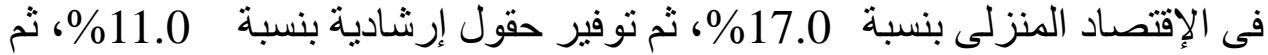

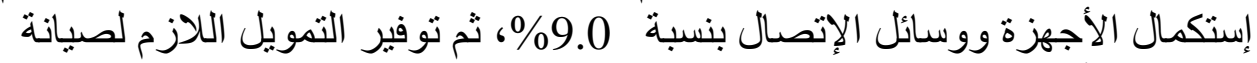
المبانى و الأجهزة و المعدات بنسبة 7.0\%

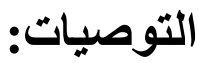 \\ فى ضوء ما أسفرت عنه نتائج البحث يمكن الخروج بالتوصيات التالية:} 1- زيادة عدد الأخصائيين الإرشاديين.

2- زيادة عدد الدورات التندريية المتخصصة. 3- توفي النشرات الإرشادية فى الوقت المناسب. 
4- وضوح الثقارير و التعليمات المكتوبة بشكل كافى. 5- توزيع النشر ات الإرشادية بشكل منتظم. 6- إستخدام الثبكة في عدد قلئل الارنيل من القرى. 78- توفير الحو افز المالية والبدلات المنات المناسبة للعاملين. 9ـ الإستعانة بالقادة المحليين من الزراع. الزاع.

1- المراجلـي، أحمد السيد (دكتور)، أساسيات الإرشاد الزراعي، دار المطبو عات

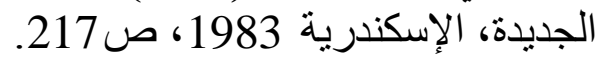

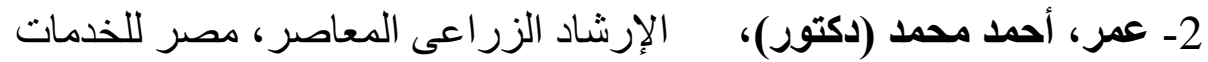

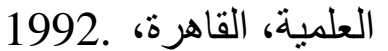

3- الخولى، حسين زكى (دكتور)، الإرشاد الزراعى، دروه فى تطوير الريف، دار

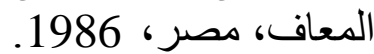

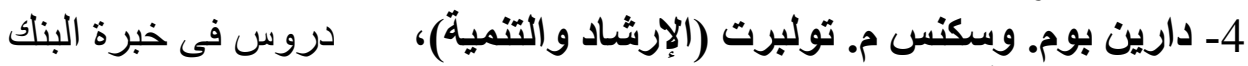

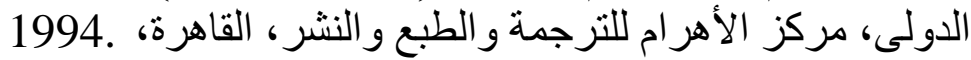

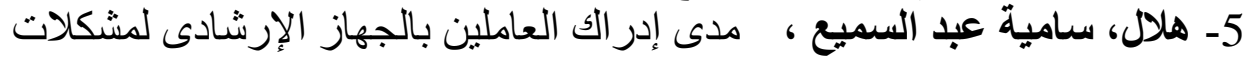

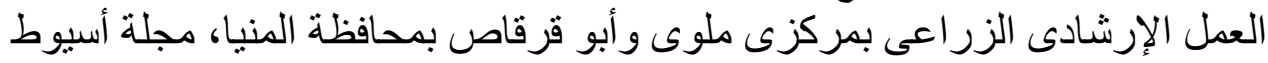

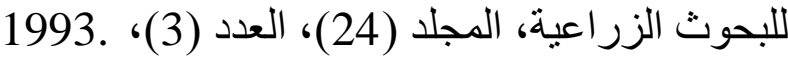

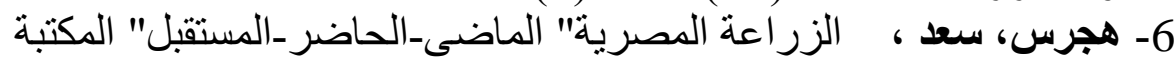

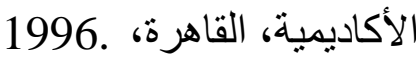

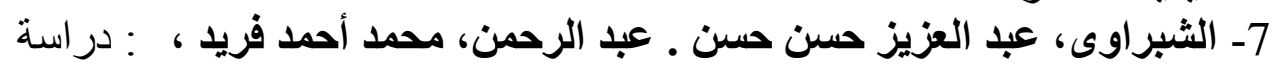

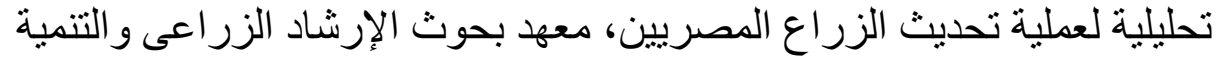

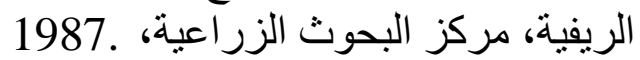

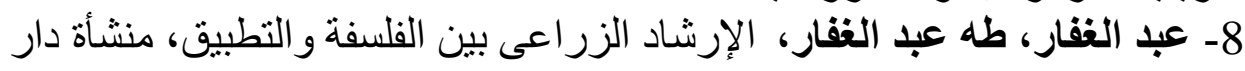

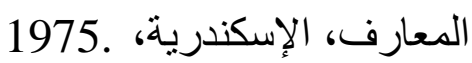
9- عثمان، سمير (دكتور) : دراسة تحليلية لبعض الطئة الطرق الإرشادية المستخدمة

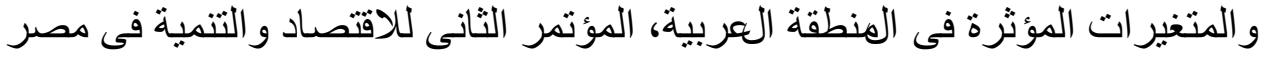

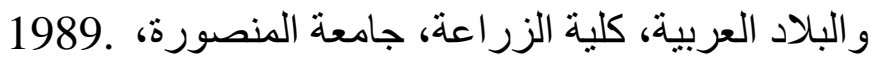

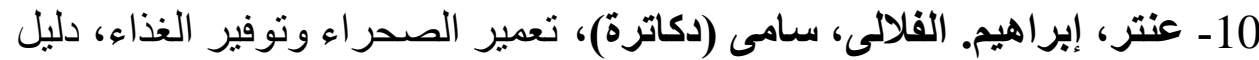

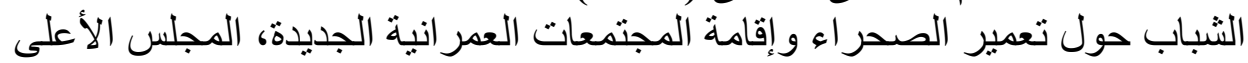

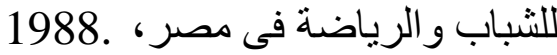
11- الطنوبي، محمد عمر ، الإنتاجية الزر اعية بين البحث العلمى و الإرشاد

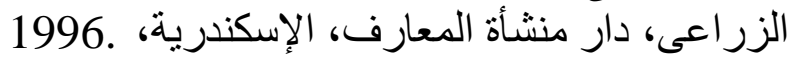




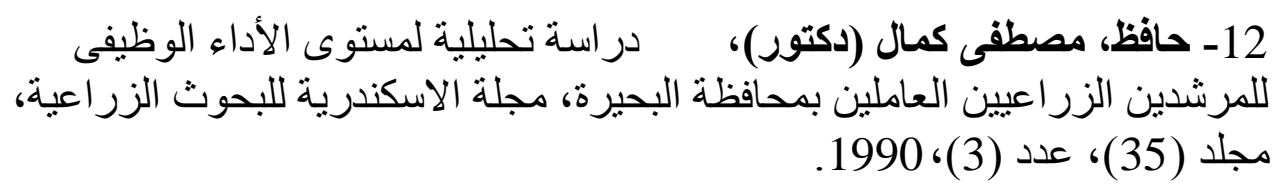

13-Rogers, Evertt M., (1983): “Diffusion of Innovation”, $3{ }^{\text {rd }}$ ed., New York, The Free Press, USA.

\title{
EFFECTIVENESS OF USING GUIDES FOR AGRICULTURAL INFORMATION SOURCES IN SHARKYIA AND DAKAHLIA GOVERNORATES
}

\author{
Shaimaa A. H. Basiony \\ Agricultural Extension, Faculty of Agriculture, Zagazig University, \\ Zagazig, Egypt.
}

\section{ABSTRACT:}

The aim of this research is to identify some of the personal characteristics of the agricultural extension workers, determine the degree of efficiency of the agricultural extension agents in the use of various sources of information (oral, written or electronic), and determine the factors affecting the efficiency of the agricultural extension agents in the use of various sources of information, whether oral, written or electronic. To identify the most important obstacles faced by agricultural extension agents in the use of different sources of information and the most important proposals to overcome them, to identify the problems faced by agricultural extension workers and their proposals for solving them

The study was conducted in the governorates of Al-Sharkiya and Dakahlia. Two centers were selected from each governorate: Mit Ghamr Center, Sinbillawin Center, Dakahlia Governorate, Husseiniya Center and Zagazig Center, Sharkiya Governorate. 50 guides were selected from each center. The sample size was 200 agricultural guides. Governorate, and data was collected using the questionnaire form by interview.

The results showed a significant correlation between the efficiency of guides in the use of verbal information sources and between age, work experience in agricultural extension, number of 
training courses, job satisfaction, motivation for achievement, feeling of community development and the direction of coordination between agricultural extension and other organizations.

The adequacy of the number of workers in the place, the qualifications of the workers, and the awareness of the workers for agricultural extension objectives

The results also showed a significant correlation between the efficiency of the guides in the use of written information resources and age, work experience in agricultural extension, number of training courses, job satisfaction, motivation for achievement, feeling of community development, And the adequacy of the number of workers in the field, the qualifications of the workers, and the awareness of the workers for agricultural extension objectives). The results also revealed a significant correlation between the efficiency of the guides in the use of electronic sources of information.

The number of training courses, job satisfaction, motivation for achievement, the sense of community development, the direction of coordination between agricultural extension and other organizations, the adequacy of the number of workers in the field, the qualifications of workers and the awareness of workers for agricultural extension purposes), while the relationship was age-, And did not confirm the statistical significance of the relationship with the sense of belonging to the community.

Keywords: Using Guides, Agricultural Information Sources, Sharkyia \& Dakahlia Governorates. 